\title{
Evaluating timescales of carbon turnover in temperate forest soils with radiocarbon data
}

\author{
Daniel Perruchoud, ${ }^{1,2}$ Fortunat Joos, ${ }^{3}$ Andreas Fischlin, ${ }^{1}$ Irka Hajdas, ${ }^{4}$ \\ and Georges Bonani ${ }^{4}$
}

\begin{abstract}
Timescales of soil organic carbon (SOC) turnover in forests were investigated wilh soil radiocarbon dala. The ${ }^{12} \mathrm{C} /{ }^{14} \mathrm{C}$ ratios were measured by accelerated mass spectroscopy on soil sampled from a deciduous temperate forest in Switzerland during $1969-1995$. The resulting $\Delta^{14} \mathrm{C}$ values $\left(125-174^{\circ} \%\right.$ oo were in line with previously published ${ }^{14} \mathrm{C}$ soil data. We applied FORCLIM-D, a model of nonliving organic matter decomposition including nine litter and two soil compartments to estimate SOC turnover times for this forest type. Carbon 14 aging in woody vegetation was explicitly accounted for. Parameters were calibrated to match radiocarbon ratios observed for forest soils at Meathop Wood, United Kingdom [Harkness et al., 1986]. We estimated that roughly 50-94\% (best estimate, $49 \%$ ) of foliar litter carbon and 11-74\% (73\%) of fine root litter carbon are eventually respired as $\mathrm{CO}_{2}$ at Meathop Wood; the rest is transferred to soil humus, where it undergoes further decomposition. Turnover times for the $0-20$ $\mathrm{cm}$ mineral soil layer ranged from $9-50$ years (25 years) for a fast overturning soil compartment comprising $38-74 \%(68 \%)$ of bulk SOC and $155-10,018$ years $(3,570$ years) for a slowly overturning compartment. For the Swiss site, SOC turnover times were in the same range. Parameter uncertainties were correlated and induced by uncertainties in ${ }^{14} \mathrm{C}$ observations from small-scale spatial inhomogeneities, sample preparation and by lack of reliable ${ }^{14} \mathrm{C}$ observations for the "prebomb" test period. Model-based estimates of soil organic $\mathrm{C}$ turnover derived from ${ }^{14} \mathrm{C}$ data must be used cautiously since they depend on the underlying model structure: bypassing litter in FORCLIM-D overestimated SOC turnover by a factor of 2.5. Such an error might remain undetected in studies lacking samples from the late 1960s and early 1970s. Thus litter $\mathrm{C}$ turnover should be included when estimating SOC turnover in temperate forests from ${ }^{14} \mathrm{C}$ data.
\end{abstract}

\section{Introduction}

Nonliving organic carbon (NLOC) sequestered in litter and mineral soils of terrestrial systems has been recognized as one of the major pools in the Earth's carbon cycle. The most recent global estimate of Batjes [1996] for soil organic C (SOC) lies at $1505 \mathrm{Pg}$

\footnotetext{
'Systems Ecology, Institute of Terrestrial Ecology, Swiss Federal Institute of Technology Zürich, Schlieren, Switzerland.

${ }^{2}$ Now at National Forest Inventory, Swiss Federal Institute for Forest, Snow and Landscape Research, Birmensdorf, Switzerland.

${ }^{3}$ Climate and Environmental Physics, Physics Institute, University of Bern, Bern, Switzerland.

${ }^{4}$ Institute of Particle Physics, Swiss Federal Institute of Technology Zürich, Hönggerberg, Switzerland.
}

Copyright 1999 by the American Geophysical Union.

Paper number 1999GB900003.

0886-6236/99/1999GB900003\$12.00
C. Thus SOC alone surpasses the $\mathrm{C}$ pools of vegetation (610 Pg C) and atmosphere (750 Pg C) by more than a factor of 2 [Schimel et al., 1995]. About $5060 \mathrm{Pg} \mathrm{C} \mathrm{yr}^{-1}$ of the global soil respiration flux of $68-77 \mathrm{Pg} \mathrm{C} \mathrm{yr} \quad$ [Schlesinger, 1977; Raich and Schlesinger, 1992; Raich and Potter, 1995] between terrestrial biota and atmosphere can be attributed to the decomposition of NLOC [McGuire et al., 1995; Post et al., 1997]. Forest soils sequester $787 \mathrm{Pg} \mathrm{C}$ [Dixon et al., 1994], and forests participate in roughly $70 \%$ of the global $\mathrm{CO}_{2}$ exchange between biosphere and atmosphere [Waring and Schlesinger, 1985]. Thus NLOC decomposition in forests plays a crucial role in the global carbon cycle, and changes in the balance between net primary production and decomposition of NLOC have the potential to alter atmospheric $\mathrm{CO}_{2}$ concentrations.

The chemical and structural heterogeneity of NLOC represents the major problem in assessing its dynamics. Only few ecosystem models have considered this is- 
sue, and SOC in particular has often been characterized by a single turnover time [Perruchoud and Fischlin, 1995]. However, $\mathrm{C}$ isotope studies have proven that this is not admissible for a description of soil organic matter (SOM) dynamics over decades to centuries [Harkness et al., 1986; Balesdent et al., 1988; Trumbore, 1993; Harrison et al., 1993a]. Many recent ecosystem models therefore represent SOC by several compartments with different turnover times [Jenkinson and Rayner, 1977; Parton et al., 1987; Jenkinson, 1990; Verberne et al., 1990; Potter et al., 1993; Parton et al., 1994] to account for the multitude of SOM transformations during decomposition. Unfortunately, all these models were originally designed and calibrated for grassland or agricultural, but none for forest soils. However, radiocarbon studies [Harrison et al., 1993b; Scharpenseel, 1993; Trumbore, 1993] have shown that land use clearly affects NLOC dynamics and prohibits an application of one model of NLOC dynamics across distinct soil types without recalibration.

Radiocarbon observations provide information about the dynamics of carbon turnover. Natural ${ }^{14} \mathrm{C}$ is cosmogenically produced in the atmosphere. It partially enters the terrestrial carbon reservoirs, where it slowly decays with a mean lifetime of 8,267 years. Over the past 10,000 years before 1950 the natural production rate of ${ }^{14} \mathrm{C}$ has remained constant within $\pm 10 \%$ [Trumbore and Druffel, 1995]. However, in the late 1950s and early 1960s atmospheric radiocarbon concentration has almost doubled owing to atomic bomb tests. After the atomic bomb test ban treaty in 1963, atmospheric ${ }^{14} \mathrm{C}$ declined owing to its continuous uptake by the terrestrial and oceanic reservoirs. This transient signal of "bomb-produced" ${ }^{14} \mathrm{C}$ is well suited to investigate timescales of carbon turnover in the range of years to decades.

Radiocarbon studies have been applied to investigate the dynamics of SOC in uncultivated [Harrison et al., 1993a; Harrison et al., 1995], cultivated [Hsieh, 1992; Harrison et al., 1993b; Hsieh, 1993], and forest soils [Harkness et al., 1986; Harrison et al., 1995] and to assess the impact of climate [Tate et al., 1995; Townsend et al., 1995; Trumbore et al., 1996] and $\mathrm{CO}_{2}$ fertilization on SOC dynamics [Harrison et al., 1993a; Harrison et al., 1995]. Typical decay times of SOC found in previous studies are in the range of a few decades for the major soil fraction and up to several millenia for more persistent structures. A depletion of fast overturning humus has been observed for cultivated relative to native soils [Harrison et al., 1993b; Harrison, 1996], whereas for a recovering forest soil, increased stocks and turnover of SOC have been reported [Harrison et al., 1995]. Increases in $\Delta^{14} \mathrm{C}$ levels for native topsoils have been related to increasing temperatures [Tate et al., 1995; Townsend et al., 1995; Trumbore et al., 1996]. Soil ${ }^{14} \mathrm{C}$ data have, however, not been utilized to link decomposition processes of litter and humified organic matter in forests, to our belief.

We used published time series of soil ${ }^{14} \mathrm{C}$ data [Harkness et al., 1986] in conjunction with FORCLIM-D [Perruchoud, 1996], a simple multicompartment model of NLOC decomposition, to quantify SOC dynamics for undisturbed northern temperate forest soils. NLOC decomposition was formulated as a sequence of first-order kinetic reactions with explicit representation of litter and humified organic matter. We represented SOM by two compartments based on the findings of Balesdent et al. [1988] and Harrison et al. [1993a] and a comparison with higher-order SOC models [Perruchoud, 1996]. Others have chosen to analyze radiocarbon in soil fractions defined by their physical or chemical characteristics. We looked at ${ }^{14} \mathrm{C}$ in bulk soil because such data were available from the literature and because it is not clear which of the existing procedures [Trumbore et al., 1989; Cambardella and Elliott, 1992; Theng et al., 1992; Buyanovsky et al., 1994; Hassink, 1995] identifies best the soil carbon fractions in terms of biodegradability. Independent and new ${ }^{14} \mathrm{C}$ enrichment data from a forest stand near Basel, Switzerland, were used to test for the plausibility of the model, its $\mathrm{C}$ turnover time estimates, and the distribution of SOC fractions in undisturbed temperate forest soils under current climatic conditions. Also included in this study is an assessment of uncertainty for these model parameter estimates. Finally, FORCLIM-D was applied to estimate the change in ${ }^{14} \mathrm{C}$ inventory between 1969 and 1989 and the $\mathrm{C}$ sequestration potential of NLOC in cold deciduous forest soils assuming $\mathrm{CO}_{2}$ fertilization of plants under transient scenarios of atmospheric $\mathrm{CO}_{2}$ increase.

\section{Materials and Methods}

\subsection{Model Description}

We used the decomposition model FORCLIM-D (Figure 1), which simulates NLOC dynamics by nine litter and two soil compartments [Perruchoud, 1996]. FORCLIM-D has been developed as part of the forest model FORCLIM [Bugmann, 1996; Fischlin et al., 1995; Bugmann and Cramer, 1998] to simulate species compositions and $\mathrm{C}$ budgets in forests of the temperate zone under current and altered climatic conditions. In this study, FORCLIM-D was run independently and driven by litter inputs from the vegetation, which were prescribed here by site-specific measurements or literature estimates.

FORCLIM-D includes a climate and litter-qualityspecific model of foliar litter decomposition and discriminates foliar (six litter types), fine root, twig, and woody litter. The carbon budget of litter compartment $i$ is given by

$$
\dot{c}_{i}(t)=-k_{i} c_{i}(t)+I_{i},
$$




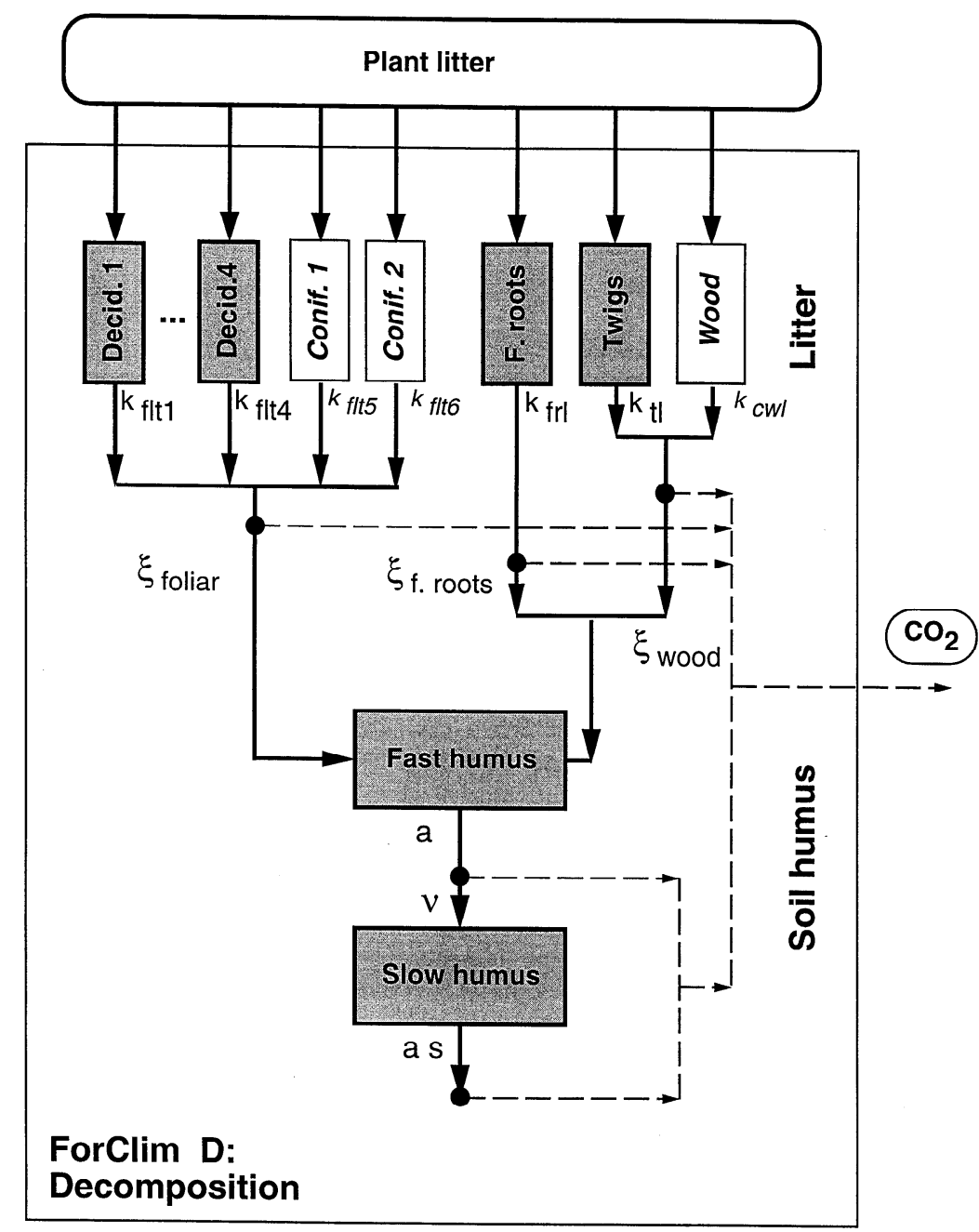

Figure 1. Structure of the decomposition model FORCLIM-D [Perruchoud, 1996]. Shaded boxes denote state variables, solid arrows indicate $\mathrm{C}$ mass fluxes, and dashed arrows describe $\mathrm{CO}_{2}$ losses associated with heterotrophic respiration. The parameters $k_{i}$ are litter decomposition rates; $\xi_{i}$ indicates the fraction of the litter efflux that is entering the fast humus compartment; the rest is respired to the atmosphere. Here $a$ and $a s$ are the turnover rates of fast and slow humus $\mathrm{C} ; \nu$ is the fraction of the flux out of the fast humus compartment that enters the slow humus compartment. The absence of needle litter (labeled conif. 1 and conif. 2) and coarse woody debris (labeled wood) for the calibration of FORCLIM-D at Meathop Wood is indicated by open rectangles.

where $c_{i}$ is the carbon mass, $k_{i}$ is the turnover rate, and $I_{i}$ is the prescribed input flux for compartment $i$ (see Table 1). On the basis of litterbag studies, decomposition rates for foliar litter are described as a function of actual evapotranspiration (AET) and lignin content of fresh litter similar to Meentemeyer [1978]:

$$
k=0.083+0.0011 \mathrm{AET}-0.832 \text { lignin. }
$$

A sensitivity analysis indicated that our results for soil radiocarbon dynamics only weakly depend on the specific formulation of litter decomposition [Matthews, 1997]. A fraction $\xi_{i}$ of the C flux from decomposing litter is transferred from litter compartment $i$ to the soil, and the rest $\left(1-\xi_{i}\right)$ is respired as $\mathrm{CO}_{2}$. The total $\mathrm{C}$ flux entering the soil is given by the sum of the humification fractions $\xi_{i}$ multiplied by the litter decomposition fluxes (i.e., turnover rate $k_{i}$ times litter mass $\left.c_{i}\right)$ :

$$
u(t)=\sum_{i} \xi_{i} k_{i} c_{i}(t)
$$

$\mathrm{SOC}$ is described by a fast $\left(c_{\mathrm{fH}}\right)$ and a slow $\left(c_{\mathrm{sH}}\right)$ overturning soil humus compartment. They represent rapid $\left(c_{\mathrm{fH}}\right)$ and recalcitrant $\left(c_{\mathrm{sH}}\right)$ topsoil carbon and arc coupled in series (Figure 1). Unlike in other SOM 
Table 1. Estimates of Litter Input and Decomposition Rates at Meathop Wood and Haumättli.

\begin{tabular}{lcc}
\hline Litter Type & $\begin{array}{c}\text { Litter Input Rate, } \\
I, \mathrm{t} \mathrm{C} \mathrm{ha}^{-1} \mathrm{yr}^{-1}\end{array}$ & $\begin{array}{c}\text { Decomposition Rate } \\
k, \mathrm{yr}^{-1}\end{array}$ \\
\hline & Meathop Wood & \\
Acer pseudoplatanus L. & 0.048 & 0.470 \\
Betula spp. & 0.168 & 0.430 \\
Corylus avellana L. & 0.212 & 0.470 \\
Fraxinus excelsior L. & 0.365 & 0.510 \\
Quercus petraea Liebelein & 0.625 & 0.430 \\
Fine roots & 0.400 & 0.690 \\
Twigs & 0.640 & 0.220 \\
& & \\
& Haumättli & \\
Foliage & 1.200 & 0.540 \\
Fine roots & 0.600 & 0.690 \\
Twigs & 0.700 & 0.220 \\
\hline
\end{tabular}

Litter inputs were taken from Sykes and Bunce [1970] and Harrison and Harkness [1993] for Meathop Wood. For Haumättli, foliar and twig litter fall was estimated based on the litter fall model of Meentemeyer et al. [1982]. Fine root litter input was assumed to equal fine root production which was determined after Nadelhoffer and Raich [1992]. All fine root litter inputs refer to the $0-5 \mathrm{~cm}$ soil layer. Decomposition rates for fine root and foliar litter were determined by matching simulated and observed levels of ${ }^{14} \mathrm{C}$ at Meathop Wood. Decomposition of twigs was adopted from Pastor and Post [1985] and Bugmann [1994]. Estimates of fine root and twig litter decomposition for Meathop Wood were also applied for the Haumättli site.

models [Parton et al., 1987; Comins and McMurtrie, 1993; Potter et al., 1993], soil microbial biomass and labile metabolites are represented here implicitly as part of above- and belowground litter as in the work by Chertov and Komarov [1996]. This hclped to reduce the number of parameters and avoid the problem of identifying this labile soil fraction, which can be problematic in forest soils [Motavalli et al., 1994]. Note that our simulations of NLOC dynamics refer to the $0-20 \mathrm{~cm}$ topsoil layer, as it stores about half of the 1-m SOC inventory in forest soils [Liski and Westman, 1995; Grigal and Ohmann, 1992; Hohmann et al., 1995], about half of the total fine root biomass [Jackson et al., 1997], and reveals significantly higher mean residence times than the underlying subsoil [Scharpenseel, 1993]. Carbon densities of the fast and slow soil compartment are described by

$$
\begin{aligned}
& \dot{c}_{\mathrm{fH}}(t)=-a c_{\mathrm{fH}}(t)+a(\hat{\mathrm{s}}), \\
& \dot{c}_{\mathrm{sH}}(t)=-a s c_{\mathrm{sH}}(t)+\nu^{\prime} a c_{\mathrm{fH}}(t),
\end{aligned}
$$

where $u$ is the input from the litter compartments, $a$ and as denote turnover rates for fast and slow humus, and $s$ is the ratio of their turnover times. Following other modeling studies [Parton et al., 1987; Rastetter et al., 1991; Comins and McMurtrie, 1993; Potter et al., 1993], we assumed a constant ratio for the turnover rates of SOC compartments across sites as no "prebomb" samples were available to better constrain the turnover rate of the slow SOC pool at the investigated sites. Here, $\nu$ controls the fraction of fast humus that is passed to the slow humus compartment (Figure 1). Thus $s / \nu$ represents the ratio of $\mathrm{C}$ masses in the fast and slow compartment at steady state. The ratios of turnover times $(s)$ and carbon inventories $(s / \nu)$ were assumed to be constant across soil depth. For calibration, equations of ${ }^{14} \mathrm{C}$ dynamics for litter and SOM were implemented as described in Appendix A.

Fluxes of dissolved organic carbon are not considered in FORCLIM-D. Dissolved organic C (DOC) fluxes are typically small compared to litter inputs above- and belowground and do not exceed $0.4 \mathrm{t} \mathrm{C}^{\mathrm{ha}}{ }^{-1} \mathrm{yr}^{-1}$ even in humid forests, where DOC leaching is an important mechanism [Currie and Aber, 1997]. Given annual precipitation sums of around $1000 \mathrm{~mm}$ at Haumättli and Meathop Wood, DOC fluxes are probably negligible there.

\subsection{Site Description and Data}

2.2.1. Meathop Wood, Great Britain. This temperate Quercus - Fraxinus - Betula type woodland was used for calibration of FORCLIM-D. The site has 
Table 2. Observed $\Delta^{14} \mathrm{C}$ and Soil Organic Carbon Inventory in Soil at Meathop Wood.

\begin{tabular}{|c|c|c|c|c|c|c|c|c|c|c|c|}
\hline \multirow[b]{2}{*}{ Year } & \multirow[b]{2}{*}{ Season } & \multicolumn{2}{|c|}{$0-5 \mathrm{~cm}$} & \multicolumn{2}{|c|}{$5-10 \mathrm{~cm}$} & \multicolumn{2}{|c|}{$10-15 \mathrm{~cm}$} & \multicolumn{2}{|c|}{$0-10 \mathrm{~cm}$} & \multicolumn{2}{|c|}{$0-15 \mathrm{~cm}$} \\
\hline & & $\Delta^{14} \mathrm{C}$ & ${ }^{12} \mathrm{C}$ & $\Delta^{14} \mathrm{C}$ & ${ }^{12} \mathrm{C}$ & $\Delta{ }^{14} \mathrm{C}$ & ${ }^{12} \mathrm{C}$ & $\Delta^{14} \mathrm{C}$ & ${ }^{12} \mathrm{C}$ & $\Delta^{14} \mathrm{C}$ & ${ }^{12} \mathrm{C}$ \\
\hline 1973 & autumn & 160 & & 10 & & -50 & & 94 & & 55 & \\
\hline 1975 & autumn & 220 & & 15 & & - & & 130 & & - & \\
\hline 1977 & autumn & 310 & 18 & 15 & 14 & -40 & 12 & 180 & 32 & 120 & 44 \\
\hline 1984 & spring & 170 & & 90 & & 50 & & 135 & & 112 & \\
\hline 1986 & spring & 130 & & 22 & & -50 & & 82 & & 47 & \\
\hline
\end{tabular}

The $\Delta^{14} \mathrm{C}$ data (in permil) for the $0-5,5-10$, and 10-15 cm layers correspond to measurements in spring or autumn [Harkness et al., 1986]. Values for the $0-10 \mathrm{~cm}$ and $0-15 \mathrm{~cm}$ layers are soil organic carbon (SOC) inventory-weighted averages (see Harrison and Harkness [1993]). Here ${ }^{12} \mathrm{C}$ denotes carbon inventories in t $\mathrm{C} \mathrm{ha}^{-1}$. For a soil depth of $0-20 \mathrm{~cm} 52 \mathrm{t} \mathrm{C} \mathrm{ha}^{-1}$ was used.

been intensively studied during the International Biological Programme [De Angelis et al., 1981] and is well documented [Bunce, 1968; Harkness et al., 1986]. The woodland at Meathop Wood was regularly coppiced for at least 300 years, being cut regularly probably at 15year intervals. The last full coppice was carried out in 1939 with a minor removal of hazel in 1946 [Harrison et al., 1990].

Litter input observations were taken from the literature (Table 1): Data of foliar and woody litter fall were equated with the average of the 3-year monitoring study of Sykes and Bunce [1970]. Estimates of fine root litter input reported by Harrison and Harkness [1993] were not depth specific. We assumed a nonlinear depth distribution with inputs of $0.4 \mathrm{t} \mathrm{C} \mathrm{ha}^{-1} \mathrm{yr}^{-1}$ for the $0-5 \mathrm{~cm}$ layer and $1.0 \mathrm{t} \mathrm{C} \mathrm{ha}^{-1} \mathrm{yr}^{-1}$ for the $0-15 \mathrm{~cm}$ layer. Fine root litter litter input was set to $1.5 \mathrm{t} \mathrm{C} \mathrm{ha}^{-1} \mathrm{yr}^{-1}$ for the $0-20 \mathrm{~cm}$ layer. Biomass and litter fall data of twigs and branches from De Angelis et al. [1981] and Harrison and Harkness [1993] were used to model $\Delta^{14} \mathrm{C}$ in woody tissue (see Appendix A).

Depth-specific SOC inventories at Meathop Wood required for initialization of soil humus compartments and calculation of ${ }^{14} \mathrm{C}$ in the $0-10$ and $0-15 \mathrm{~cm}$ soil layer (Table 2) were available from Harrison et al. [1990].
Here SOC is concentrated in the top mineral soil layers: The $0-5 \mathrm{~cm}$ soil layer contains $22 \%$ of $\mathrm{C}$ stored in organic plus mineral soils down to $50 \mathrm{~cm}$ depth (total NLOC), whereas in the top $15 \mathrm{~cm}$, even $64 \%$ are stored. Compared to this, the overlying organic layer contains only $6 \%$ of total NLOC. Carbon 14 data for calibration were taken from Harkness et al. [1986] and Harrison and Harkness [1993]. Two soil samples (collection dates 1977 and 1982) were excluded for calibration. They do not originate from the origina! field campaign of Harkness et al. [1986] (A. F. Harrison, Institute of Terrestrial Ecology, Grange-over-Sands, personal communication, 1997) and are higher than published ${ }^{14} \mathrm{C}$ levels measured in topsoil profiles around the globe. We could not find any evidence in the literature and any plausible explanation for their high radiocarbon concentrations.

2.2.2. Haumättli, Switzerland. A forest reserve ("Naturreservat") located $20 \mathrm{~km}$ east of Basel on flat terrain in close proximity (about $200 \mathrm{~m}$ ) to the river Rhine [Kuhn, 1990; Burri, 1996] was used for model testing. This stand is characterized by vegetation dominated by Fraxinus excelsior L., with Acer pseudoplatanus L. and Fagus silvatica L. as secondary species. The forest site Haumättli was managed previous to the 1920s and since then has been left untouched. Thereby,

Table 3. Organic Carbon Content, Soil Bulk Density and Soil Isotopic Data at Haumättli

\begin{tabular}{lccccl}
\hline $\begin{array}{l}\text { Collection } \\
\text { Year }\end{array}$ & $\begin{array}{c}\mathrm{C} \text { Content, } \\
\%\end{array}$ & $\begin{array}{c}\text { Bulk Density, } \\
\mathrm{g} / \mathrm{cm}^{3}\end{array}$ & $\begin{array}{c}\Delta,{ }^{14} \mathrm{C}, \\
\%\end{array}$ & $\begin{array}{c}\delta^{13} \mathrm{C} \\
\%\end{array}$ & $\begin{array}{l}\text { Laboratory } \\
\text { Number }\end{array}$ \\
\hline 1969 & 2.38 & - & 1.58 & -25.7 & ETH-15004 \\
1988 & 2.28 & - & 174 & -21.9 & ETH-15006 \\
1993 & 2.40 & 1.12 & 164 & -26.3 & ETH-15007 \\
1995 & - & - & 125 & -28.5 & ETH-15329 \\
\hline
\end{tabular}

All data are for the $0-5 \mathrm{~cm}$ forest soil layer sampled in 1969, 1988 [Kuhn, 1990], 1993 [Burri, 1996], and 1995 (this study). Soil organic matter was measured following aggregation of seven soil cores collected within 2 ha [Burri, 1996]. Bulk densities for all collection dates were assumed to equal the value measured in 1993 by Burri [1996]. Isotopic ratios were measured by accelerated mass spectroscopy (AMS) at the AMS laboratory, Zürich (PSI/ETH). 
the site was allowed to revert from mainly spruce dominated vegetation to its natural state (broadleaf vegetation) (J. Steck, personal communication, 1998). Although soils at Haumättli are classified as Fluvisols by their pedogenetic background, there have been no signs of periodic floodings in the past few decades (N. Kuhn, personal communication, 1998).

We determined foliar and total litter fall according to Meentemeyer et al. [1982]: Twig litter fall was calculated as the difference between total and foliar litter fall. Fine root litter input was determined via fine root production from total aboveground litter fall $\mathrm{C}$ [Nadelhoffer and Raich, 1992]. For the required estimate of AET (namely, $595 \mathrm{~mm} \mathrm{yr}^{-1}$ ), simulation results of FORCLIM at Basel [Bugmann, 1994] were invoked (Table 1).

At Haumättli, SOC content and ${ }^{14} \mathrm{C}$ for the $0-5 \mathrm{~cm}$ mineral soil layer were determined from archived and recently collected soils. Ungrounded soil material was available for 1969, 1988 [Kuhn, 1990], and 1993 [Burri, 1996], and additional samples were collected in 1995 (this study). All samples were obtained by bulking seven soil cores from within 2 ha [Burri, 1996]. The SOC inventory was calculated by multiplying $\mathrm{C}$ concentrations and bulk soil density of the soil fraction < $2 \mathrm{~mm}$ (Table 3). Accelerated mass spectroscopy (AMS) was selected for measuring isotope ratios of bulk soil. AMS targets were prepared according to the protocol of Rutberg et al. [1996] and measured at the PSI/ETH facility in Zürich, Switzerland (Table 3).

\subsection{Experimental Design}

The model was calibrated for the Meathop Wood site assurming steady state conditions for ${ }^{12} \mathrm{C}$ fluxes in model calibration and model testing. Turnover rates of litter $k_{i}$ and soil humus $(a, a s)$, humification ratios $\xi_{i}$, the humus transfer coefficient $\nu$, and the prescribed ${ }^{12} \mathrm{C}$ litter inputs from vegetation $I_{i}$ were kept constant in time. This is justified as net carbon storage contributes little to the ${ }^{14} \mathrm{C}$ flux into the terrestrial biota [Joos and Bruno, 1998].

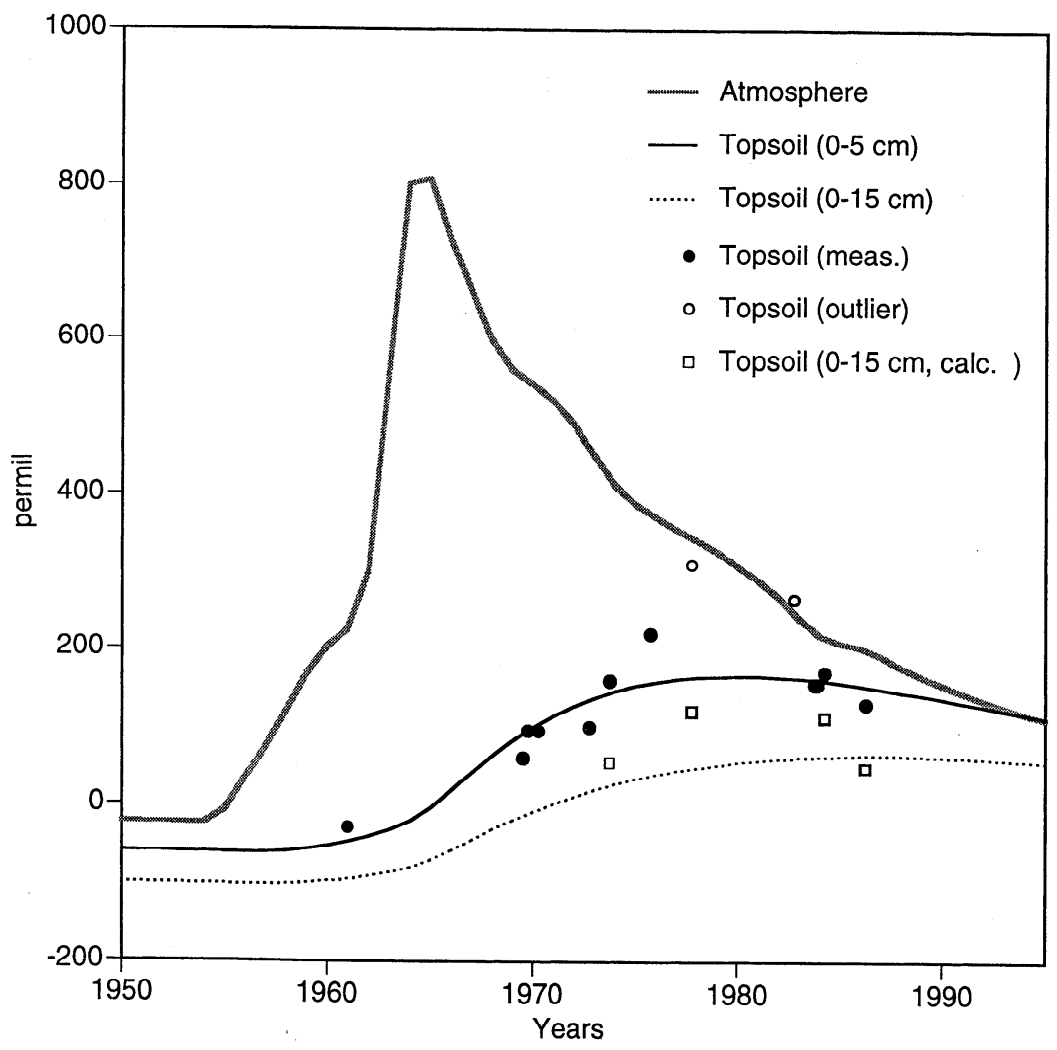

Figure 2. Comparison of simulated and observed ${ }^{14} \mathrm{C}$ in the $0-5 \mathrm{~cm}$ and $0-15 \mathrm{~cm}$ mineral soil layer at Meathop Wood. Simulations of ${ }^{14} \mathrm{C}$ in soil organic carbon (SOC) were driven by the atmospheric ${ }^{14} \mathrm{C}$ history for the Northern Hemisphere of Enting et al. [1994]. Carbon 14 data were taken from Harkness et al. [1986] and Harrison and Harkness [1993] (see Table 2). Two data points (collection dates 1977 and 1982 denoted by "Topsoil (outlier)") were not used for parameter identification. (see text). All ${ }^{14} \mathrm{C}$ data are expressed in $\%{ }^{14} \mathrm{C}$. The analytical measurement error is $10 \%{ }^{14} \mathrm{C}$, natural soil ${ }^{14} \mathrm{C}$ variability lies around $50-100 \%$ o [Harrison et al., 1990]. 
Carbon 14 simulations were initialized for an atmospheric ${ }^{14} \mathrm{C}$ ratio of $\Delta^{14} \mathrm{C}_{\mathrm{A}} \equiv 0 \%$. The model was run from 1930 to 1995 forced by the observed atmospheric ${ }^{14} \mathrm{C}$ history for the Northern Hemisphere (Figure 2) by Enting et al. [1994]. Atmospheric ${ }^{14} \mathrm{C}$ ratios $\left[\Delta^{14} \mathrm{C}_{\mathrm{A}}(t)\right]$ were prescribed in $\Delta^{14} \mathrm{C}$ notation, which implicitly accounts for fractionation effects. The $\Delta^{14} \mathrm{C}$ in living wood was explicitly modeled by a one-compartment model to account for the slower growth and turnover rates of this tissue. On the other hand an instantaneous transfer of the atmospheric $\Delta^{14} \mathrm{C}$ signal was assumed for foliar and fine root litter (see Appendix A).

For the decomposition rate of twig litter, a value of $k_{\mathrm{tl}}=0.22 \mathrm{yr}^{-1}$ was adopted in accordance with Pastor and Post [1985] and Bugmann [1994]. The decomposition rate of fine root litter was tuned until simulated and observed levels of $\Delta^{14} \mathrm{C}$ measured on "undecomposed plant rootlets" in the 0-5 cm soil layer [Harrison et al., 1990] visually matched (Table 1). Similarly, decomposition rates for foliar litter were constrained by varying AET in (2) to match radiocarbon measurements in the leaf layer [Harkness et al., 1986]. The $\xi_{\text {wood }}$ was determined using the estimate of Mattson et al. [1987] for $\mathrm{CO}_{2}$ losses of decomposing fine and coarse woody debris $(\approx 55 \%)$.

Next the parameters $\xi_{\text {foliar }}, \xi_{\text {f.roots }}, s$, and $s / \nu$ were determined by the global least squares optimization algorithm SUFI [Abbaspour et al., 1997]. We used the root-mean-square error (RMSE) defined by

$$
\operatorname{RMSE}:=\sqrt{\frac{1}{N} \sum_{i=1}^{N}\left[x_{\text {meas }}\left(t_{i}\right)-x_{\text {sim }}\left(t_{i}\right)\right]^{2}}
$$

as target function, where $x_{\text {meas }}$ and $x_{\text {sim }}$ refer to measured and simulated ${ }^{14} \mathrm{C}$ values, respectively in the $0-5$ cm soil layer (Table 2).

Finally, the turnover rate for the fast humus compartment $a$ was calculated from total soil carbon inventory data $\left(c_{\mathrm{SOC}}\right)$ for the $0-5 \mathrm{~cm}$ layer [Harrison and Harkness, 1993], the soil $\mathrm{C}$ input from litter decomposition $u$, and the ratio of fast and slow humus $\mathrm{C}$ mass at steady state $(s / \nu)$

$$
a=\frac{1}{c_{\mathrm{SOC}}}\left(1+\frac{\nu}{s}\right) u \text {. }
$$

The influence of climate on SOC dynamics is implicitly included since high SOC stocks, associated with low temperature [Burke et al., 1989], imply low SOC turnover rates and vice versa. On the basis of uniform mixing of the SOC pool observed at Meathop Wood [Harrison et al., 1990] FORCLIM-D was subsequently recalibrated for greater soil depth as follows: The parameters $\xi_{\text {foliar }}, \xi_{\text {f.roots }}, \xi_{\text {wood }}, s$, and $s / \nu$ identified for the $0-5 \mathrm{~cm}$ layer were also applied to a soil depth of
0-15 $\mathrm{cm}$ and $0-20 \mathrm{~cm}$. This means that the ratio of turnover times $(s)$ and $\mathrm{C}$ masses $(s / \nu)$ was assumed to be the same for all depths. Absolute values of the turnover rates for the $0-15 \mathrm{~cm}$ and $0-20 \mathrm{~cm}$ layer, however, varied according to (7) and depth-specific soil inventories $\left(c_{\mathrm{SOC}}\right.$, see Table 2$)$ and fine root litter inputs (see 2.2). The assumption of homogeneity for the 0-20 $\mathrm{cm}$ soil layer was justified by the high biological activity (earthworms) at Meathop Wood [Harrison et al., 1990].

The site Haumättli was used to test the model parameters. Decomposition rates for foliar litter were recalculated according to (2) with a lignin concentration of $24 \%$ (of dry weight organic matter) for mixed foliar litter. AET was assumed to be $595 \mathrm{~mm} \mathrm{yr}^{-1}$ (see above). Fine root and woody litter decomposition rates and the SOC parameters $\xi_{i}, \nu$, and $s$ were adopted from Meathop Wood. The turnover rate $a$ for Haumättli was derived via (7). The required SOC inventory $\left(13.2 \mathrm{t} \mathrm{C} \mathrm{ha}^{-1}\right.$ for the $0-5 \mathrm{~cm}$ layer) was averaged from measured carbon concentrations of samples collected in 1969, 1988, and 1993 (A. Burri, University of Zürich, personal communication, 1996).

\section{Results}

\subsection{Model Calibration}

At Meathop Wood we found best estimates for the turnover times of 11 years for $68 \%$ of the SOC and around 1,560 years for the rest at $0-5 \mathrm{~cm}$ soil depth (Table 4). A reasonable agreement between simulated and calculated ${ }^{14} \mathrm{C}$ data was obtained for the $0-15 \mathrm{~cm}$ soil layer (Figure 2) with turnover times of about 23 and 3,340 years. Our extrapolation for the top 0-20 cm soil layer, which is thought to be affected by environmental changes most directly [Parton et al., 1993; Schimel et al., 1994; McGuire et al., 1995; Melillo et al., 1995], resulted in turnover time estimates of 25 and 3,570 years for fast and slow humus, respectively.

Next we investigated uncertainties of estimated parameters (Table 5) as resulting from uncertainties in soil radiocarbon obscrvations ( $0-5$ crn layer). Best estimates for the parameters $\xi_{\text {foliar }}, \xi_{\text {f.roots }}, s$, and $s / \nu$ were obtained by a global stepwise search; that is, model simulations were carried out on a stepwise refined four-dimensional grid in the parameter space and the RMSE evaluated for each grid point. The minimum for RMSE was 0.0262 , corresponding to a mean deviation of $\pm 26 \%$ in modeled versus measured $\Delta{ }^{14} \mathrm{C}$. The span of $52 \%$ is comparable to the range of $74 \%$ in replicate $\Delta{ }^{14} \mathrm{C}$ measurements reported by Harrison et al. [1990] for the 0-5 $\mathrm{cm}$ soil layer. This variation in replicate samples is much larger than the measurement precision and could be due to small-scale inhomogeneities in the soil layer and sample preparation. 
Table 4. Comparison of Published Turnover Times and Fractions of Fast and Slow Overturning Humus in the Topsoil Layers

\begin{tabular}{ccclll}
\hline $\begin{array}{c}\text { Humus Turnover Time, } \\
\text { years }\end{array}$ & Fast Humus & \multicolumn{1}{c}{ Soil Type } & Depth & Reference \\
\cline { 1 - 4 } Fast & Slow & Fraction, $\%$ & & & \\
\hline 25 & 3,700 & 75 & native forest and grassland & A horizon & Harrison et al. [1993a] \\
25 & 3,700 & 50 & cultivated & A horizon & Harrison et al. $[1993 \mathrm{~b}]$ \\
25 & 4,700 & 82 & native forest and grassland & A horizon & Harrison et al. [1995] \\
25 & 4,700 & 83 & native forest and grassland & A horizon & Harrison $[1996]$ \\
12 & 4,700 & 70 & recovering forest soil & A horizon & Harrison et al. $[1995]$ \\
$15-30$ & ND & $70-7 \%$ & forest and pasture & $20 \mathrm{~cm}$ & Townsend et al. $[1995]$ \\
$35-62$ & ND & $50-90$ & temperate forest & $12-23 \mathrm{~cm}$ & Trumbore et al. $[1996]$ \\
$9-50$ & $155-10,018$ & $38-74$ & native temperate forest & $20 \mathrm{~cm}$ & this study \\
\hline
\end{tabular}

The estimates of Harrison et al. [1993a], Harrison et al. [1993b], Harrison et al. [1995], and Harrison [1996] are based on a worldwide compilation of forest and grassland soil samples. Those of Townsend et al. [1995] and Trumbore et al. [1995] are from an altitudinal transect in Hawaii and the Sierra Nevada. The range of this data reflects turnover time estimates derived for different sites and not an uncertainty as the range indicated for this study. The latter resulted from parameter intervals obtained for root-mean-square error $(\mathrm{RMSE})=0.03$ (see Table 5) via equation (7). Abbreviation: ND indicates not determined.

Parameter ranges associated with RMSE $\leq 0.030$ were determined to estimate uncertainties in model parameters (Table 5$)$. We found that $6-50 \%\left(\xi_{\text {foliar }}\right)$ of foliar litter $\mathrm{C}$ and $27-90 \%$ ( $\left.\xi_{\text {f.roots }}\right)$ of fine root litter was humified during decomposition and the rest respired to the atmosphere. The uncertainty range for the humification ratio of fine root litter $\left(\xi_{\text {f.roots }}\right)$ was larger than for foliar litter $\left(\xi_{\text {foliar }}\right)$ as the latter dominates soil $\mathrm{C}$ inputs at the soil surface (Table 1 ). Less than $9 \%$ of the fast humus C, which amounts to $38-74 \%$ of bulk SOC,

Table 5. FORCLIM-D Model Parameter Values and Uncertainty Ranges at Meathop Wood

\begin{tabular}{lcccc}
\hline & & \multicolumn{3}{c}{ RMSE } \\
\cline { 3 - 5 } Parameter & Default & 0.03 & 0.028 & 0.027 \\
\hline$\xi_{\text {foliar }}$ & 0.51 & $0.06-0.50$ & $0.06-0.50$ & $0.39-0.50$ \\
$\xi_{\text {f.roots }}$ & 0.27 & $0.27-0.90$ & $0.27-0.90$ & $0.32-0.84$ \\
$\nu$ & 0.00329 & $0.0018-0.0887$ & $0.0018-0.0187$ & $0.0018-0.0082$ \\
& & & & \\
$c_{\mathrm{fH}}, \%$ & 68 & $38-74$ & $57-74$ & $65-74$ \\
$c_{\mathrm{sH}}, \%$ & 32 & $26-62$ & $26-43$ & $26-35$ \\
$\tau_{\mathrm{fH}}$, years & 25 & $9-50$ & $13-50$ & $15-29$ \\
$\tau_{\mathrm{sH}}$, years & 3,570 & $155-10,018$ & $511-10,018$ & $993-5,838$ \\
\hline
\end{tabular}

Defaults and uncertainty ranges are given for FORCLIM-D model parameters (see Fig 1) that control the dynamics of litter and topsoil C $(0-20 \mathrm{~cm})$. The root-mean-square error (RMSE, see equation (6)) determined from observed and simulated ${ }^{14} \mathrm{C}$ data was of the order of the measured soil ${ }^{14} \mathrm{C}$ variability [Harrison et al., 1990] and within $15 \%$ of the final minimal value (RMSE $=0.0262)$. Here $\xi_{\text {foliar }}, \xi_{\text {f.roots }}$, and $\nu$ are dimensionless transfer ratios that control the fraction of decomposing litter $\mathrm{C}$ being transferred to the fast humus compartment $\xi_{i}$ and the fractional $\mathrm{C}$ flux between the fast and the slow humus compartment $\nu ; c_{\mathrm{fH}}, c_{\mathrm{sH}}$ denote the percentage of fast and slow humus in $20 \mathrm{~cm}$ topsoil, and $\tau_{\mathrm{fH}}, \tau_{\mathrm{sH}}$ are the respective turnover times in years. The parameters $\xi_{\text {foliar }}, \xi_{\text {f.roots }}, s$, and $s / \nu$ were identified with SUFI [Abbaspour et al., 1997] and $a$ constrained by (7). The ratio $s / \nu$, representing the ratio of ${ }^{12} \mathrm{C}$ masses for the fast and slow humus compartment, was expressed by $c_{\mathrm{fH}}$ and $c_{\mathrm{SH}}$ and rate parameters $(a, 1 /(a s))$ converted to figures for $\mathrm{C}$ turnover via $\tau_{\mathrm{fH}}=1 / a$ and $\tau_{\mathrm{sH}}=1 /(a \cdot s)$. Owing to homogeneity of the topsoil at Meathop Wood, $\xi_{\text {foliar }}, \xi_{\text {f.roots }}, s$, and $\nu$ were derived from ${ }^{14} \mathrm{C}$ data for the $0-5 \mathrm{~cm}$ soil layer and extrapolated to $0-20 \mathrm{~cm}$ soil depth. 


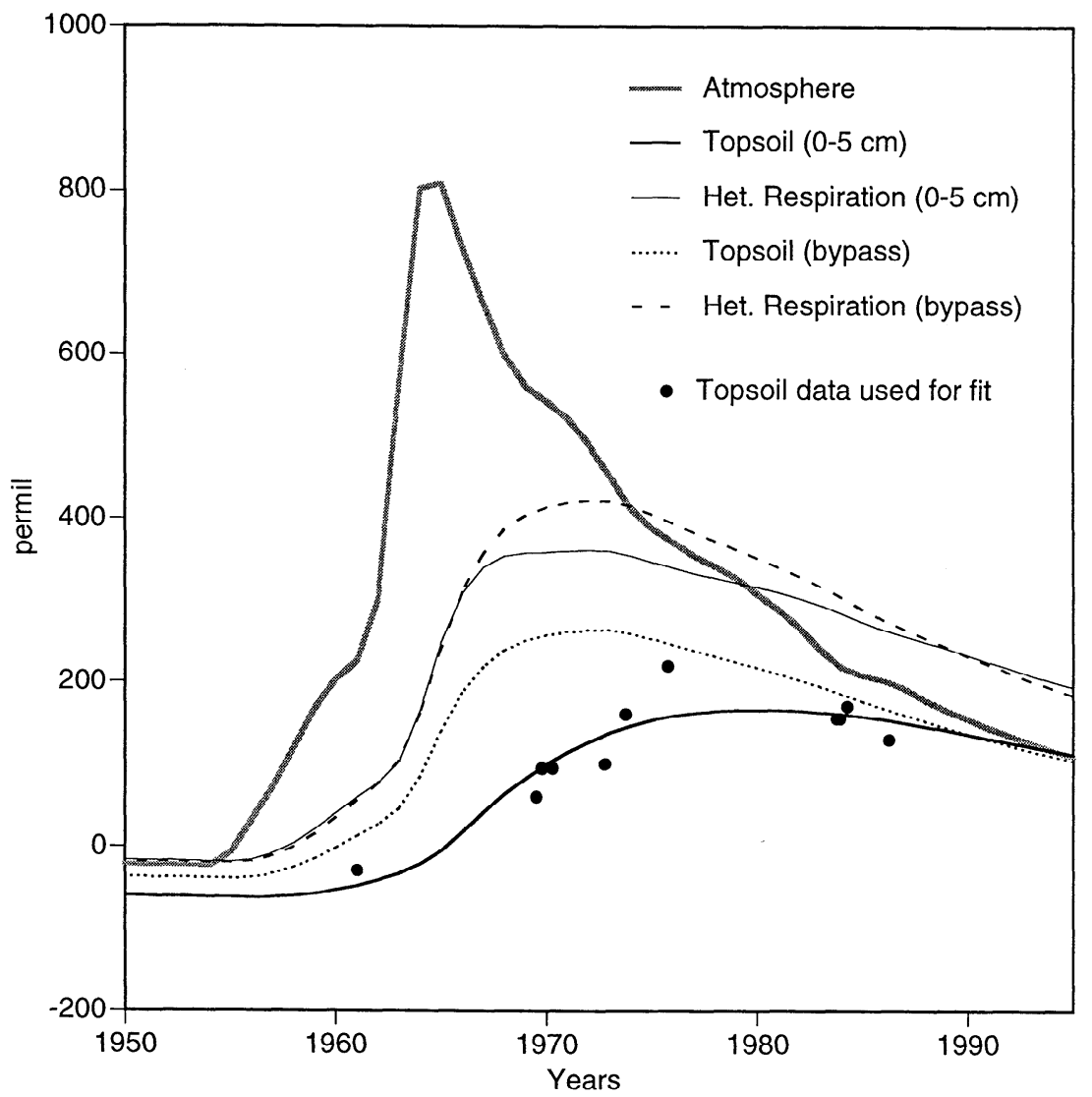

Figure 3. Effect of litter mineralization and humification on simulated ${ }^{14} \mathrm{C}$ in soil and heterotrophically respired $\mathrm{CO}_{2}$ at Meathop Wood for a soil depth of $5 \mathrm{~cm}$. Atmospheric ${ }^{14} \mathrm{C}$ data for the Northern Hemisphere are from Enting et al. [1994]. Note the higher levels of simulated ${ }^{14} \mathrm{C}$ if plant litter is bypassed ("bypass" simulation) compared to the data of Harkness et al. [1986] for the early 1970s and the convergence of the two simulations in the late $1980 \mathrm{~s}$. All ${ }^{14} \mathrm{C}$ data are expressed in $\%$ o $\Delta^{14} \mathrm{C}$.

was passed to the slow humus compartment (parameter $\nu)$. Turnover times for the fast and slow compartment were $9-50$ and $155-10,018$ years, respectively. A more reliable determination of the relative size of the fast and slow humus compartment and the turnover time of the latter was hampered by the absence of samples for the period prior to the atomic tests.

Parameters for humification ratios, soil reservoir sizes, and turnover times are correlated in FORCLIM-D (see (3) and (7)). This can also be seen from the SOC response to a step change in litter input (see (9)). A numerical analysis of (9) based on the parameter ranges obtained for RMSE $=0.03$ (Table 5) revealed that the step response of SOC varied by no more than $16 \%$ (after $t=15$ years) relative to the equilibrium response within a few centuries. Thus the general response of FORCLIM-D to a decadal scale transient carbon perturbation is better determined by the ${ }^{14} \mathrm{C}$ data than reflected by the uncertainty of individual parameters.

Is it necessary to use a coupled litter-soil model to quantify SOC dynamics via ${ }^{14} \mathrm{C}$ in soils? To an- swer this question we simulated ${ }^{14} \mathrm{C}$ enrichment in mineral soil bypassing litter decomposition and associated $\mathrm{CO}_{2}$ mineralization processes, assuming instead an instantaneous, complete transfer of ${ }^{14} \mathrm{C}$ from fresh plant litter to the soil. This was achieved by setting $k_{i}=500 \mathrm{yr}^{-1}$ (instantaneous litter decomposition) and $\xi_{i}=1.0$ (no respiration losses from litter) for all litter types. Thereby, soil radiocarbon input fluxes were driven by the atmospheric isotopic ratio except for the input from woody vegetation. Figure 3 shows the anticipated rise in ${ }^{14} \mathrm{C}$ enrichment and the convergence in the mid-1980s for the "bypassing litter" run compared to our default run for a soil depth of $5 \mathrm{~cm}$. Because of (3) and (7) we obtained lower values for the turnover times in this case, namely, 5 (fast humus) and 712 years (slow humus) for a $5 \mathrm{~cm}$ soil depth as compared to 11 and 1,560 years when litter dynamic was included. Turnover times recalculated for the $0-20 \mathrm{~cm}$ soil layer via (7) were 10 and 1,421 years in the bypassing litter run. Although these values were still within the uncertainty range estimated above, they were systematically 


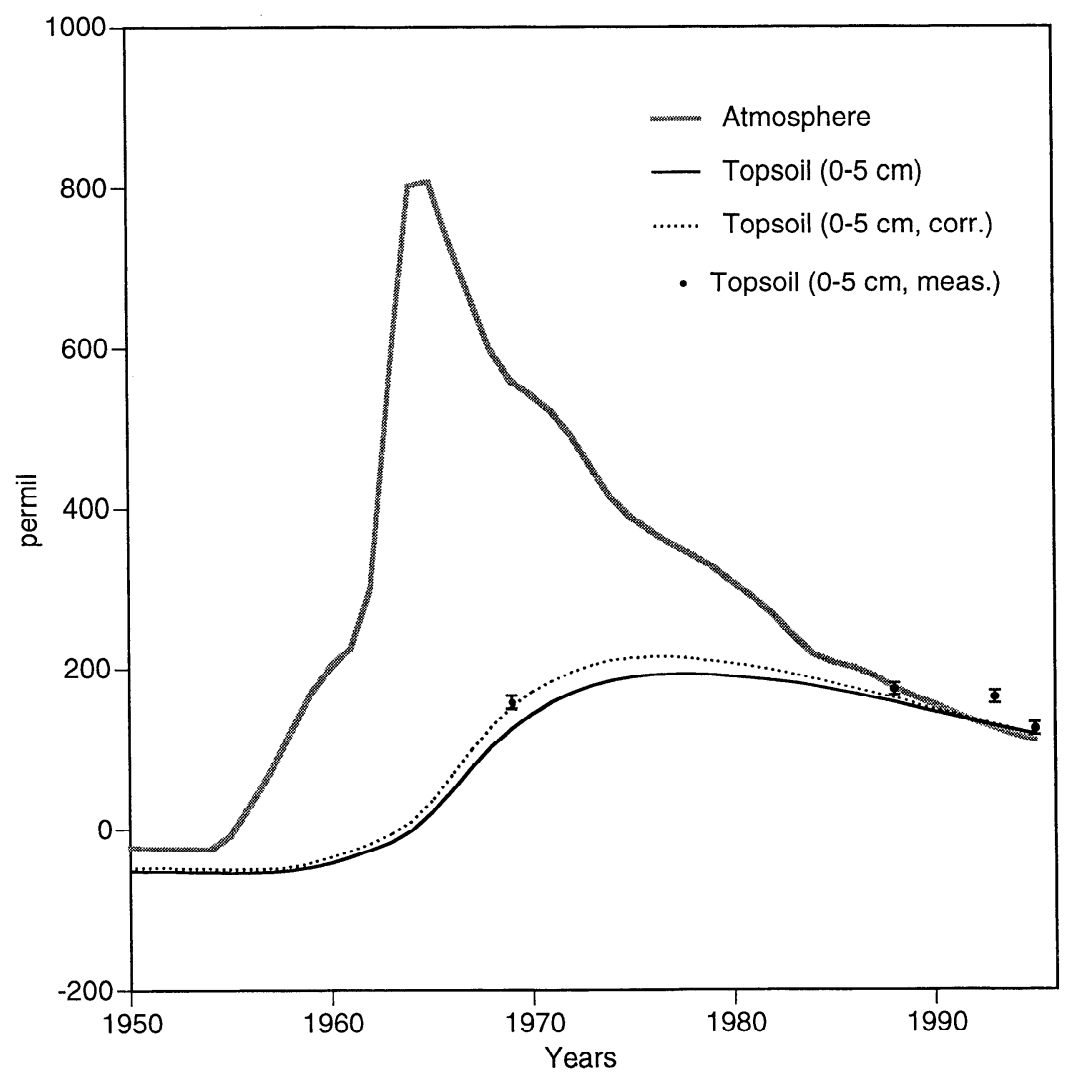

Figure 4. Comparison of simulated and measured ${ }^{14} \mathrm{C}$ for the deciduous forest stand Haumättli investigated by Kuhn [1990] and Burri [1996]. Defaults for litter input and decomposition rates are given in Table 1 and resulted in an underestimation of measured ${ }^{14} \mathrm{C}$ values ("Topsoil $(0-5$ $\mathrm{cm})$ "). A readjustment of litter inputs by $+10 \%\left(1.32 \mathrm{t} \mathrm{C} \mathrm{ha}^{-1} \mathrm{yr}^{-1}\right)$ and SOC by $-10 \%$ (11.9 t $\mathrm{C} \mathrm{ha}{ }^{-1}$ instead of $13.2 \mathrm{t} \mathrm{C} \mathrm{ha}^{-1}$ ) considerably improved the agreement between simulation and data ("Topsoil (0-5 cm, corr.)"). All ${ }^{14} \mathrm{C}$ enrichment data (Table 3) are expressed in ${ }^{\circ}{ }_{\mathrm{oo}} \Delta{ }^{14} \mathrm{C}$. Measurement errors from accelerated mass spectroscopy $\left( \pm 7-9 \%{ }^{14} \mathrm{C}\right)$ are indicated by error bars.

lower than our best estimates. This suggests that the complete litter-soil dynamics should be tracked when comparing modeled versus observed radiocarbon levels. Otherwise, turnover times of soil organic matter will be systematically underestimated.

\subsection{Model Testing and Applications}

Simulations with FORCLIM-D at Haumättli using estimated litter inputs (Table 1) and measured SOC inventory for this Swiss site combined with parameters $\left(\xi_{\text {foliar }}, \xi_{\text {f.roots }}, \xi_{\text {wood }}, s / \nu\right.$, and $\left.s\right)$ derived for Meathop Wood underestimated somewhat the measured ${ }^{14} \mathrm{C}$ enrichment in the $0-5 \mathrm{~cm}$ soil layer. The turnover times for fast and slow humus were 8 and 1,178 years. The mismatch between modeled and observed values was within the range of natural variability of ${ }^{14} \mathrm{C}$ observations in soils [Harrison et al., 1990] and was remedied by slight adjustments of the litter input rate and SOC inventory (Figure 4). Foliar litter fall rates were increased by $10 \%$ to $1.32 \mathrm{t} \mathrm{C} \mathrm{ha}^{-1} \mathrm{yr}^{-1}$, which seems jus- tified given the intrasite variability of foliar litter fall of $12 \%$ (standard deviation) for deciduous trees across the Swiss Plateau [Lüscher, 1991]. Additionally, the SOC inventory was reduced by $10 \%$ to $11.9 \mathrm{t} \mathrm{C} \mathrm{ha}^{-1}$, which seems a reasonable estimate for the combined errors of bulk density and \%C concentration [Trumbore et al., 1995]. Humification ratios $\xi_{i}$, humus transfer $\nu$, and the scaling factor $s$ remained unchanged. For these settings our best estimate of SOM dynamics ( $0-5 \mathrm{~cm}$ soil layer) resulted in turnover times of 7 and 1,006 years for fast and slow humus, respectively. In summary, turnover of $\mathrm{C}$ in soil at the Swiss site and at Meathop Wood were indistinguishable within the uncertainty of the observations. For model applications we used parameter values derived for the Meathop Wood site.

It has been suggested recently to use observations of the ${ }^{14} \mathrm{C} /{ }^{12} \mathrm{C}$ ratio of heterotrophically respired $\mathrm{CO}_{2}$ to determine turnover timescales of terrestrial biospheric C [Dörr and Münnich, 1986; Joos et al., 1997]. We simulated the mean annual ${ }^{14} \mathrm{C} /{ }^{12} \mathrm{C}$ ratio in het- 


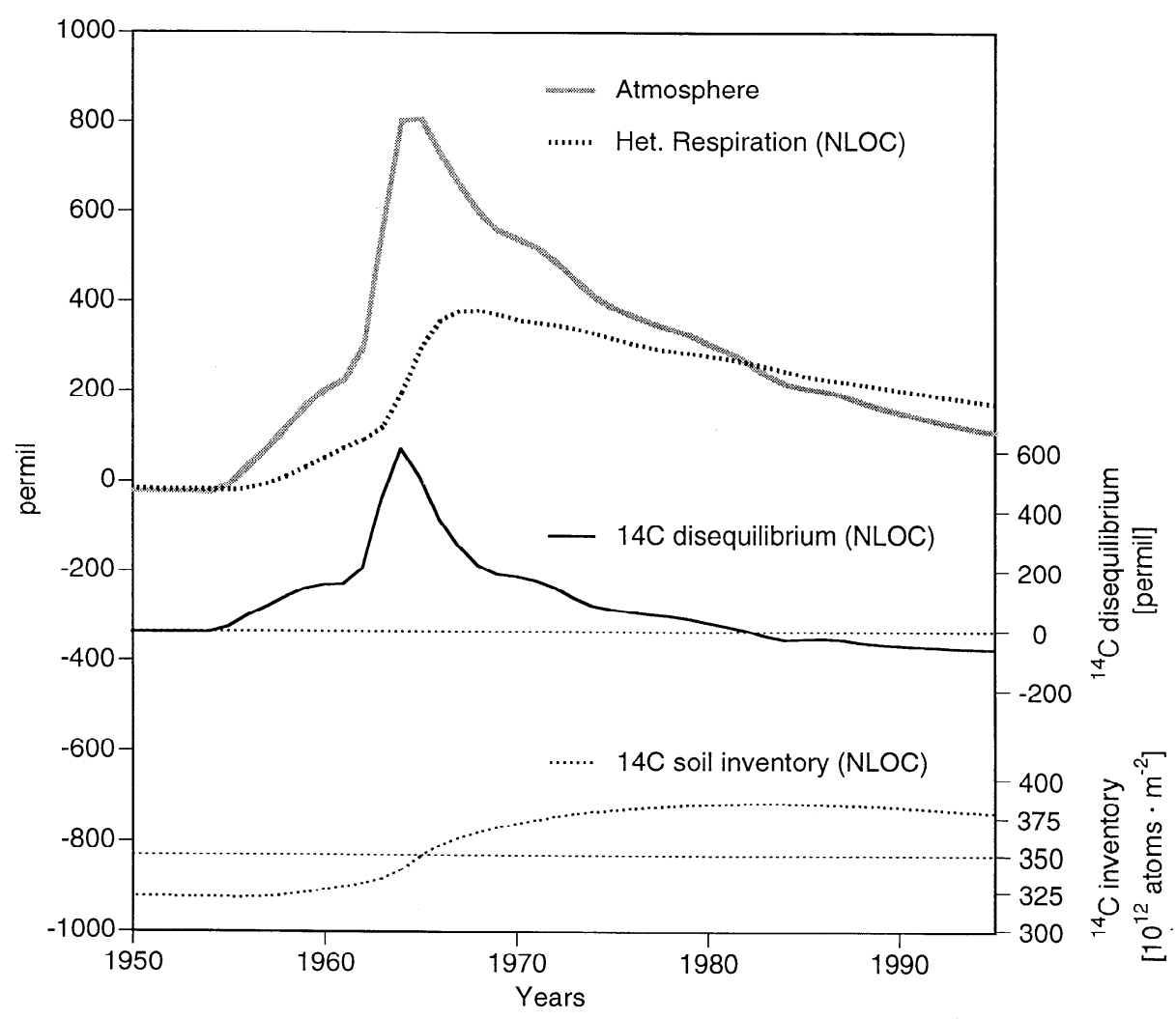

Figure 5. Simulated $\Delta^{14} \mathrm{C}$ air-biota disequilibrium and ${ }^{14} \mathrm{C}$ soil inventory at Meathop Wood for litter and soil $(0-20 \mathrm{~cm})$. The $\Delta^{14} \mathrm{C}$ air-biota disequilibrium was calculated as difference of observed atmospheric $\Delta^{14} \mathrm{C}$ [Enting et al., 1994] minus simulated $\Delta^{14} \mathrm{C}$ in heterotrophically respired $\mathrm{CO}_{2}$. The ${ }^{14} \mathrm{C}$ soil inventory was determined from equation (8). Carbon 14 data are expressed in $\%$ o $\Delta^{14} \mathrm{C}$. The ${ }^{14} \mathrm{C}$ soil inventory is given in units of $10^{12}$ atoms $\mathrm{m}^{-2}$.

erotrophically respired $\mathrm{CO}_{2}$ (Figure 5 , top) to calculate the ${ }^{14} \mathrm{C}$ air-biota disequilibrium as defined by the difference in atmospheric (assimilated) and heterotrophically respired $\Delta^{14} \mathrm{C}$ for the $0-20 \mathrm{~cm}$ soil layer. The $\Delta^{14} \mathrm{C}$ disequilibrium increased initially with a peak at $604.3 \%$ around 1964 (Figure 5, middle). Thereafter the air-biota disequilibrium decreased monotonously, crossed over in 1982 and reached a value of $-48.5 \%$ by 1990.

We also used FORCLIM-D to assess the bomb radiocarbon inventory in SOC of cold deciduous forests. The modcled radiocarbon inventory of soils, ${ }^{14} c_{\mathrm{NLOC}}$, in units of ${ }^{14} \mathrm{C}$ atoms $\mathrm{m}^{-2}$ was obtained by

$$
{ }^{14} c_{\mathrm{NLOC}}(t)=\frac{N_{\mathrm{av}}}{0.12}{ }^{14} \mathrm{R}_{\mathrm{st}}\left\{\sum_{j}\left[1+\frac{\Delta{ }^{14} \mathrm{C}_{j}(t)}{1000}\right]\right\}{ }^{12} c_{j}
$$

where $\Delta{ }^{14} \mathrm{C}_{j}(t)$ is the simulated ${ }^{14} \mathrm{C} /{ }^{12} \mathrm{C}$ ratio of litter and topsoil in permil ( $j=$ foliar, f.root, woody litter and $\mathrm{SOC}),{ }^{14} \mathrm{R}_{\text {stand }}=1.176 \times 10^{-12}$ is the standard isotopic ratio of ${ }^{14} \mathrm{C} /{ }^{12} \mathrm{C}, N_{\mathrm{av}}=6.022 \times 10^{23}$ is the number of atoms per mol, and ${ }^{12} c_{j}$ is the $\mathrm{C}$ content in $\mathrm{C} \mathrm{Cha}^{-1}$ of litter and soil compartments. A factor $0.12=12 / 100$ was used to convert mol to atoms and relate the radiocarbon inventory to $\mathrm{m}^{2}$. NLOC contained $322 \times 10^{12}$ atoms $\mathrm{m}^{-2}$ in 1950 (85\% in SOC) and increased to attain its maximum in $1983\left(385 \times 10^{12}\right.$ atoms $\left.\mathrm{m}^{-2}\right)$ (Figure 5, bottom). For the period 1965-1989, NLOC's ${ }^{14} \mathrm{C}$ inventory increased by $33 \times 10^{12}$ atoms $\mathrm{m}^{-2}$. We obtained a bomb inventory rise of $4.4 \times 10^{26}$ atoms for soils between 1965 and 1989 by multiplying the above estimate with the area covered by cold deciduous forests $\left(13.2 \times 10^{12} \mathrm{~m}^{2}\right)$. This is about $5-10 \%$ of the estimated increase in the global terrestrial biosphere system.

FORCLIM-D was used to investigate the soil response for instantaneous changes of SOC inputs. In Figure 6 , SOC dynamics in the $0-20 \mathrm{~cm}$ soil layer is shown for a step change in SOC input ( $\delta$ in (9)) by $10 \%, 20 \%$, and $35 \%$. Changes over the first century were dominated by accumulation of fast humus, while for slow humus the buildup took place on the timescale of a millennium (not shown). Even for the instantaneous litter input changes assumed here, more than 10 years were required to change the SOC inventory by $10 \%$ or more for all cases. 


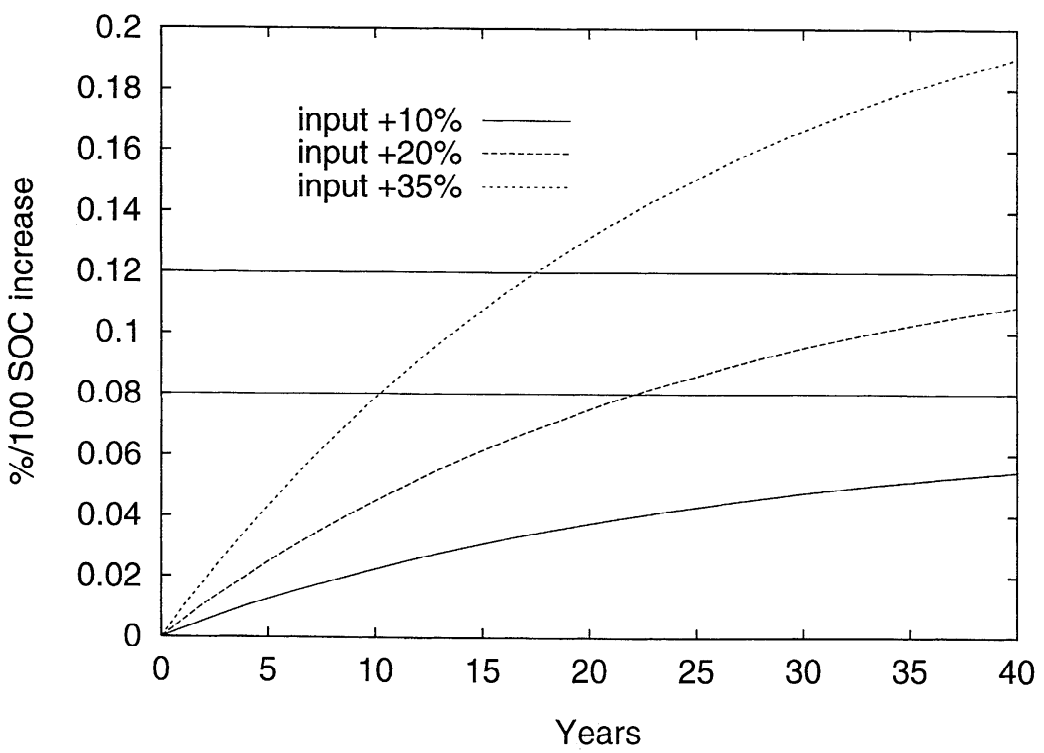

Figure 6. Simulated relative response (expressed as [percent per 100]) of C stocks (fast plus slow humus) for step increases of $\mathrm{C}$ input at Meathop Wood (see equation (9)). We assumed a turnover time of 25 years for fast humus with a contribution of $68 \%$ to the SOC inventory of the 0-20 cm mineral soil layer. Relative increases of input fluxes considered were 10, 20, and $35 \%$, which compare to the response of SOC to an instantaneous doubling of atmospheric $\mathrm{CO}_{2}$ for growth enhancement factors $\beta$ of $0.1,0.2$, and 0.35 , respectively. The horizontal lines at $8 \%$ and $12 \%$ emphasize the differences for distinct $\beta$ factors and overall slow response of SOC.

Finally, the transient response of NLOC stocks (litter plus $0-20 \mathrm{~cm}$ soil humus) to changes in primary productivity as a consequence of a postulated $\mathrm{CO}_{2}$ fertilization were assessed (Figure 7 and Table 6). We used the logarithmic relationship $\left\{1+\beta \ln \left[\mathrm{CO}_{2}(\mathrm{t}) / \mathrm{CO}_{2}\left(\mathrm{t}_{0}\right)\right]\right\}$ between the increase in atmospheric $\mathrm{CO}_{2}$ and litter input with $\beta=0.35$. This value was derived from mean total tree dry mass increases for a doubling of $\mathrm{CO}_{2}$ in controlled-exposure studies [Wullschleger et al., 1995]. For transient simulations between 1765 and 2100, atmospheric $\mathrm{CO}_{2}$ was prescribed according to observations until 1990 and then following IS92a and S550 [Schimel et al., 1995]. Atmospheric $\mathrm{CO}_{2}$ roughly follows the present trend under the IS92a scenario. According to the S550 pathway, future growth in atmospheric $\mathrm{CO}_{2}$ is decreasing and atmospheric levels eventually stabilize at 550 parts per million by volume (ppmv), i.e., about twice the preindustrial level.

Owing to the accelerated increase of atmospheric $\mathrm{CO}_{2}$ in the recent past, the increase of modeled NLOC stocks between 1770-1960 and 1960-2000 equaled each other (i.e., $2.6 \%$ relative to 1770 A.D.). For the next century, simulated NLOC accumulation diverged under the two $\mathrm{CO}_{2}$ scenarios. We obtained an increase in NLOC of $14.2 \%$ (relative to 1770 ) by 2100 for $\mathrm{S} 550$. Annual NLOC accumulation rates did not change between the past decade and the end of the next century under. this $\mathrm{CO}_{2}$ scenario. For the IS92a scenario, NLOC accumulation rates increased further during the course of the next century, leading to an enhancement of NLOC stocks of $19.9 \%$ by 2100 (Figure 7 ).

These figures were used to estimate the potential of C sequestration of cold deciduous forest soils (Table 6). On the basis of an analysis of regional SOC inventories (Perruchoud [1996], Tablc 2.4), we assumed NLOC densities of 50-70 t C ha ${ }^{-1}$ for litter and soil down to 20 $\mathrm{cm}$ depth and an area extent of $13.2 \times 10^{12} \mathrm{~m}^{-2}$ for this vegetation type [Dai and Fung, 1993; King et al., 1997]. For the 1980 s we obtained an NLOC accumulation rate of $0.04-0.06 \mathrm{Gt} \mathrm{C} \mathrm{yr}^{-1}$ in cold deciduous forest soils. These soils cover $\approx 11 \%$ of the global terrestrial surface (deserts and ice neglected King et al. [1997]). If the postulated fertilization is indeed real and if the carbon dynamics of forest soils would be the same for nonforest soils, then global NLOC accumulation would be of the order of $0.4-0.6 \mathrm{Gt} \mathrm{C} \mathrm{yr}{ }^{-1}$ for the 1980s. This corresponds to about $30-45 \%$ of the global C "imbalance" (1.3 Gt $\mathrm{C} \mathrm{yr}^{-1}$ ) for the last decade [Schimel et al., 1996].

\section{Discussion and Conclusions}

There is general agreement between the findings from previous studies [Harrison et al., 1993a; Harrison et al., 


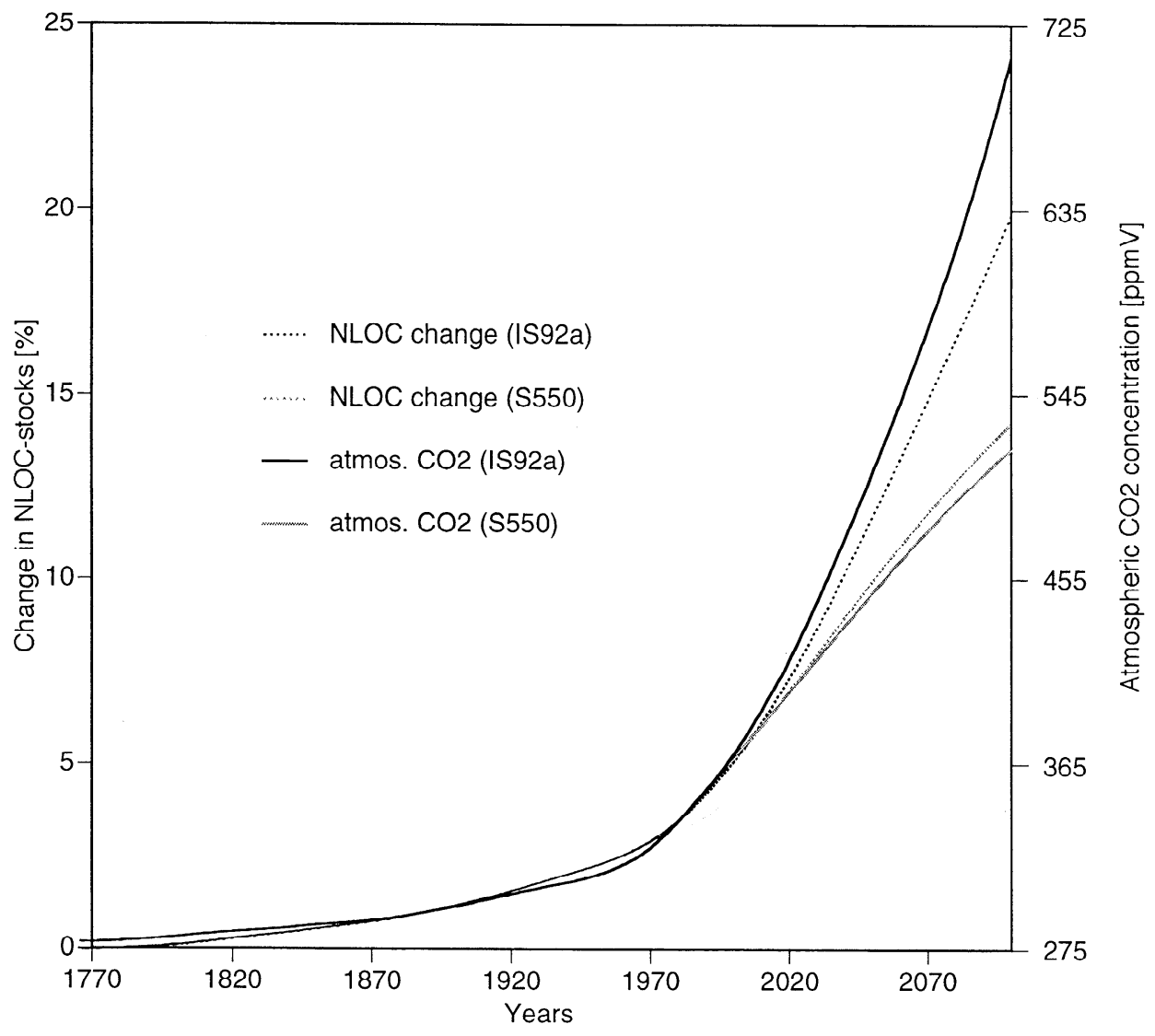

Figure 7. Relative changes in nonliving organic carbon (NLOC) stocks (left axis) as induced by $\mathrm{CO}_{2}$ fertilization. Here productivity is assumed to increase logarithmically $(\beta=0.35)$ with atmospheric $\mathrm{CO}_{2}$ (right axis) as prescribed according to the Intergovernmental Panel on Climate Change IS92a scenario and S550 pathway. The S550 profile approaches stabilization at roughly twice the preindustrial $\mathrm{CO}_{2}$ level (i.e., 550 parts per million by volume) by 2150 . The concentration for IS92a was calculated from prescribed anthropogenic carbon emissions with the Bern model [Joos et al., 1996; Schimel et al., 1996]. Simulated NLOC changes represent changes of carbon stocks sequestered by litter and soil organic matter in the 0-20 $\mathrm{cm}$ mineral soil.

1993b; Harrison et al., 1995; Townsend et al., 1995; Trumbore et al., 1996] and our quantification of SOC dynamics for Meathop Wood (Table 4); the agreement of turnover times and SOC distribution is particularly good for estimates obtained by a global compilation of ${ }^{14} \mathrm{C}$ enrichment data from native forest and grassland soils [Harrison et al., 1993a; Harrison et al., 1993b]. Variations in ${ }^{14} \mathrm{C}$ at the stand/plot level have been related to land use [Harrison et al., 1993b; Harrison, 1996; Harrison et al., 1995] and climate. [Tate et al., 1995; Townsend et al., 1995; Trumbore et al., 1996]. Trumbore et al. [1996] have investigated SOC dynamics in temperate forest soils under coniferous vegetation. For soils with comparable mean annual air temperature (MAT) ("Shaver" and "Corbett", MAT $\approx 8^{\circ} \mathrm{C}$; Meathop Wood, MAT $=7.8^{\circ} \mathrm{C}$ ) they obtained estimates of SOC turnover times of $35-55$ years for a maximum soil depth of $20-23 \mathrm{~cm}$. This is slightly higher than our turnover estimate of 25 years for fast humus accounting for $68 \%$ of topsoil $\mathrm{C}$ but is comparable within the general uncertainty of the ${ }^{14} \mathrm{C}$ method (Table 5).

As pointed out by Aber et al. [1990], p. 2201 "very few studies have dealt with the role of litter decay in the formation of stable forest soil organic matter." However, this process eventually determines how plant response affects $\mathrm{C}$ storage in the soil. We have estimated from soil ${ }^{14} \mathrm{C}$ observations how much of the foliar and fine root littcr $\mathrm{C}$ is respired to the atmosphere and how much is converted to SOC (Table 5). Our results suggest that more than $50 \%$ of the decomposing foliar litter leaves the ground as $\mathrm{CO}_{2}$. The respective fraction for fine root litter is about three quarters, but is highly uncertain (Table 5). A better estimate for the fine root litter humification ratio could probably have been obtained if more ${ }^{14} \mathrm{C}$ data from soil layers at greater depth $(5-15 \mathrm{~cm})$, where the influence of foliar litter is smaller, 
Table 6. Change in Soil and Litter Carbon Storage Induced by a Postulated $\mathrm{CO}_{2}$ Fertilization of Vegetation

\begin{tabular}{ccc}
\hline \multirow{2}{*}{ Period } & \multicolumn{2}{c}{ NLOC Change, Gt C } \\
\cline { 2 - 3 } & IS92a & S550 \\
\hline & NLOC, 1770 & A.D. $=66$ Gt C \\
$1770-2000$ & $3.4(5.1)$ & $3.4(5.1)$ \\
$1770-2050$ & $7.7(11.7)$ & $6.6(10.0)$ \\
$1770-2100$ & $13.1(19.9)$ & $9.4(14.2)$ \\
$1980-1989$ & $0.4(0.7)$ & $0.4(0.7)$ \\
$2090-2099$ & $1.0(1.5)$ & $0.4(0.7)$ \\
& NLOC,1770 & A.D. $=92$ Gt C \\
& $4.7(5.1)$ & $4.7(5.1)$ \\
$1770-2000$ & $10.8(11.7)$ & $9.2(10.0)$ \\
$1770-2050$ & $18.4(19.9)$ & $13.1(14.2)$ \\
$1770-2100$ & $0.6(0.7)$ & $0.6(0.7)$ \\
$1980-1989$ & $1.4(1.5)$ & $0.6(0.7)$ \\
$2090-2099$ & 1.6 \\
\hline
\end{tabular}

Shown is simulated carbon storage in nonliving organic carbon (NLOC) as induced by a postulated plant growth enhancement due to increasing atmospheric $\mathrm{CO}_{2}$ levels. The same effect was assumed for vegetation growth and litter production for the sake of simplicity. Atmospheric $\mathrm{CO}_{2}$ levels were prescribed according to the Intergovernmental Panel on Climate Change scenarios IS92a and S550. Two different estimates of the preindustrial NLOC stock were considered as calculated by assuming an area of $13.2 \times 10^{12} \mathrm{~m}^{-2}$ for cold deciduous forests [Dai and Fung, 1993; King $\epsilon t$ al., 1997] and initial $\mathrm{C}$ densities of litter and mineral soil (0-20 cm soil depth) of 50 and $70 \mathrm{t} \mathrm{C} \mathrm{ha}^{-1}$, respectively [Perruchoud, 1996]. Numbers in parentheses indicate the change (in percent) relative to the preindustrial carbon stock.

aRelative changes in percent are given in parentheses.

had been available. Within the soil compartment we find that more than $90 \%$ of the $\mathrm{C}$ that is overturning on a decadal timescale is respired to the atmosphere; the rest is stable or very slowly decaying material.

The model was applied to estimate the potential of forest soils to sequester anthropogenic $\mathrm{C}$ under increasing atmospheric $\mathrm{CO}_{2}$. The following two assumptions were made: (1) atmospheric and climatic changes have not changed the respiration rates for NLOC and (2) primary productivity and litter production have increased in pace with atmospheric $\mathrm{CO}_{2}$. Under these settings, cold deciduous forests potentially accumulated 0.04$0.06 \mathrm{Gt} \mathrm{C} \mathrm{yr}^{-1}$ in litter and soils during the 1980s. Although turnover and thus response times of soils in the boreal and the tropical zone differ, a tentative spatial extrapolation yielded a global potential NLOC accumu-

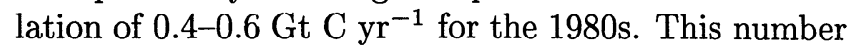
would explain about $30-45 \%$ of the "imbalance" in the contemporary C budget and is comparable to SOC accumulation estimates of Post et al. [1997] (0.7 Gt C $\mathrm{yr}^{-1}$, globally) and Harrison et al. [1993a] and Harrison [1996] (0.5-0.7 Gt C yr ${ }^{-1}$, nonwetland soils).

The assessment of the soil's potential for storing anthropogenic carbon is simplistic for sevcral reasons. First, a long-term $\mathrm{CO}_{2}$ fertilization effect for mature forests ecosystems is highly uncertain [Kirschbaum and Fischlin, 1996; Melillo et al., 1996]. Second, the response of species assemblages [Bazzaz et al., 1993] and C stocks [Schimel et al., 1994] to increases of atmospheric $\mathrm{CO}_{2}$ under multiple resource limitations (light, nutrient, water) was not considered here. Third, it is not clear how plants growing under elevated $\mathrm{CO}_{2}$ affect soil processes. NLOC accumulation is one possibility, but increased fine root production and root rhizodeposition could also stimulate microbial activity and deteriorate SOC levels [Körner and Arnone III, 1992; Norby et al., 1992; Rouhier et al., 1994].

Note that turnover times for NLOC and its high spatial variability make it unlikely that increases in NLOC stocks would be detected by field monitoring studies within less than a few decades. Moreover, Huntington et al. [1988] have concluded that a massive sampling is required, particularly in heterogeneous landscapes, to obtain statistically reasonable estimates of $\mathrm{C}$ changes in topsoils. While the step response of SOC for increased litter input already took more than a decade (Figure 6), gradual changes, e.g., by $\mathrm{CO}_{2}$ or nitrogen fertilization, would even take longer to become visible. Models therefore remain a promising way to assess the NLOC dynamics at regional or higher scales.

An important but difficult aspect of model building is assessing the uncertainty of model structure and model parameters. The age distribution of SOC is viewed to cover a continuum of timescales ranging from years to millenia. Our scil representation was by two compartments only with turnover times of about 25 years $[1 / a]$ and 3,600 years $[1 /(a s)]$ governing the age distribution of SOC by two exponential functions with characteristic rate parameters $a$ and $a s$ (see (9)). A representation of SOC by two boxes is justified by the following arguments: On one hand, the uncertainty of available ${ }^{14} \mathrm{C}$ data does not allow us to reasonably determine the parameter values for a model with an improved resolution. On the other hand, a two-box representation can roughly explain the slow long-term sccretion rate of humus observed during soil formation [Schlesinger, 1990] and the large potential of soils to respond to changes in $\mathrm{C}$ input fluxes as induced by climatic and atmospheric concentration changes on timescales of a few decades [Townsend et al., 1995].

Related to the uncertainties in model structure is the neglect of an explicit description of ${ }^{14} \mathrm{C}$ turnover in litter and vegetation in analyses of soil radiocarbon 
data. Rafter and Stout [1970] and Harkness et al. [1986] have observed higher than atmospheric levels of $\Delta^{14} \mathrm{C}$ in the litter layer of forest soils for the "post-bomb" period. This proves that soil ${ }^{14} \mathrm{C}$ dynamics is not directly driven by the atmospheric ${ }^{14} \mathrm{C}$ signal (Figure 3 ). Simulations at Meathop Wood revealed that calculated turnover times are, in fact, sensitive to the representation of litter decomposition. A direct, undelayed transfer of the atmospheric ${ }^{14} \mathrm{C}$ signal into the soil compartment lowered turnover times by a factor of 2.5 relative to our standard calibration. Bypassing the breakdown and mineralization of forest litter and transferring the ${ }^{14} \mathrm{C}$ signal from the vegetation directly to the soil had the effect of a premature ${ }^{14} \mathrm{C}$ enrichment in mineral soil (see Figure 3, 1960-1980 A.D.). This would not be detected in ${ }^{14} \mathrm{C}$ simulations of SOC without litter representation if soil samples covering the period 1965-1975 A.D. were missing. We conclude that the dynamics of the complete vegetation-litter-soil system should be explicitly described when determining turnover times of $\mathrm{SOC}$ from ${ }^{14} \mathrm{C}$ data in order to avoid a systematic bias.

We estimated the range of possible parameter values within the two-box representation of SOC as coupled to nine litter pools. Individual parameter values of the soil submodel varied over a wide range while still matching soil ${ }^{14} \mathrm{C}$ observations within their uncertainty. Parameter uncertainties turned out to be correlated; litter humification ratios $\left(\xi_{\text {foliar }}, \xi_{\text {î.root }}\right)$ were high when the fast humus fraction $(s / \nu)$ was low and vice versa. Highly asymmetric distributions of the range around the best estimates were found for other parameters. Since the individual parameters are not independent in FORCLIM$\mathrm{D}$, the overali response of SOC to a decadal scale forcing is much better constrained by ${ }^{14} \mathrm{C}$ data than uncertainties of inciividual parameters might suggest. Our results indicate that radiocarbon soil measurements are useful for quantifying SOC dynamics, although additional constraints are necessary to reduce uncertainties of single model parameters.

Are there other ways to utilize radiocarbon observations for a better understanding of terrestrial C turnover? Dörr and Münnich [1986] have demonstrated the usefulness of $\Delta^{14} \mathrm{C}$ observations for quantifying the age of heterotrophically respired $\mathrm{C}$ by measurements of soil $\mathrm{CO}_{2}$ samples taken during the early 1980s. Dörr and Münnich [1986] have found that $\Delta^{14} \mathrm{C}$ values in soil $\mathrm{CO}_{2}$ are close to atmospheric levels in summer when respiration fluxes are largest. In winter, root respiration and decomposition of young material are reduced relative to the decomposition of more refractory SOM and observed $\Delta^{14} \mathrm{C}$ in soil $\mathrm{CO}_{2}$ are about $50-100 \%$ oo lower at a grassland and a beech spruce forest site. The annually averaged observed $\Delta^{14} \mathrm{C}$ in respired $\mathrm{CO}_{2}$ is close to atmospheric levels around 1982/1983. Our simulations revealed a near match of ${ }^{14} \mathrm{C}$ in heterotropically respired $\mathrm{CO}_{2}$ and atmospheric $\mathrm{CO}_{2}$ around 1982 and are thus in close agreement with these observations. Using contemporary radiocarbon information could also lead to an improved quantification of SOC dynamics via the ${ }^{14} \mathrm{C}$ air-biota disequilibrium (Figure 5 , middle). Joos et al. [1997] found, in a global modeling study, a spatial variability between assimilated and respired $\mathrm{C}$ of several tens of $\% \Delta^{14} \mathrm{C}$, which can potentially be detected. The advantage of measuring ${ }^{11} \mathrm{C}$ concentrations in heterotrophically respired $\mathrm{CO}_{2}$ is the reduction of spatial variability by air mixing in comparison to soil ${ }^{14} \mathrm{C}$.

After the bomb test ban treaties were set in place in the early 1960s, the total radiocarbon content of the atmosphere-biosphere-ocean system should have remained roughly constant. This budget constancy additionally constrains $\mathrm{C}$ cycle models that include the three relatively rapidly exchanging reservoirs, atmosphere, biosphere, and ocean [Hesshaimer et al., 1994; Joos, 1994]. Until now the biospheric change in radiocarbon inventory has been assessed by simple global box models of the terrestrial biota. In this study, FORCLIM-D was used to interpolate soil ${ }^{14} \mathrm{C}$ data to estimate in a consistent way the increase in local ${ }^{14} \mathrm{C}$ inventories. Required in the future for testing our understanding of the global ${ }^{14} \mathrm{C}$ budget are estimates of global terrestrial ${ }^{14} \mathrm{C}$ storage derived by applying models that match local ${ }^{14} \mathrm{C}$ observations.

Soils continue to be one of the great unknowns in the context of global $\mathrm{C}$ cycling owing to their high spatial variability. Radiocarbon observations offer a good possibility for improving our understanding of the global $\mathrm{C}$ cycling in different ways; radiocarbon is, e.g., used in standard tests to assess the timescales of surface to deep mixing in ocean $\mathrm{C}$ cycle models by comparison of modeled and observed oceanic ${ }^{14} \mathrm{C}$ distributions. Radiocarbon observations also offer an opportunity to improve our understanding of the $\mathrm{C}$ dynamics in terrestrial biota as shown in this study. However, to track terrestrial carbon dynamics and constrain terrestrial ecosystem models, the utilization of ${ }^{1.4} \mathrm{C}$ data needs to be improved. Measurements of radiocarbon on samples of heterotrophically respired $\mathrm{CO}_{2}$ could be a means to do so.

\section{Appendix A: Carbon 14 Equations for NLOC Dynamics}

The following equation system was implemented to identify rate parameters controlling the dynamics of NLOC by ${ }^{14} \mathrm{C}$ enrichment data, for a complete derivation of the model equations, refer to p.67 in Perruchoud [1996].

$$
\begin{gathered}
\text { Litter } \\
{ }^{14} \dot{c}_{\mathrm{nt}_{\mathrm{i}}}(t)={ }^{12} \mathcal{F}_{\mathrm{V}, \mathrm{Ct}_{\mathrm{i}}}{ }^{14} \mathrm{R}_{\mathrm{st}} \Delta-\underset{\text { foliar litter }}{\left(k_{\mathrm{ftt}}+\lambda\right){ }^{14} c_{\mathrm{ftt}_{\mathrm{i}}}(t)}
\end{gathered}
$$




$$
\begin{aligned}
& { }^{14} \dot{c}_{\text {frl }}(t)={ }^{12} \mathcal{F}_{\mathrm{V}, \text { frl }}{ }^{14} \mathrm{R}_{\mathrm{st}} \Delta-\left(k_{\mathrm{frl}}+\lambda\right){ }^{14} c_{\mathrm{frl}}(t) \\
& \text { fine root litter }
\end{aligned}
$$

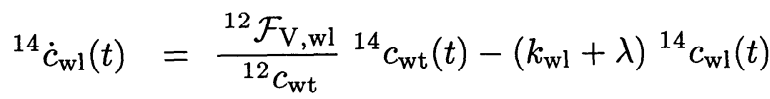

$$
\begin{aligned}
& \text { woody litter }
\end{aligned}
$$

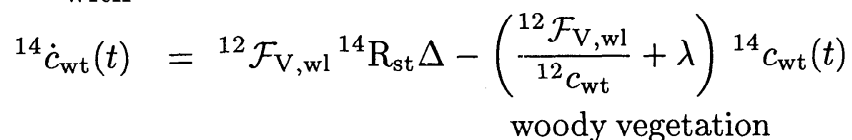

where

$$
\Delta=\left(1+\frac{\Delta^{14} \mathcal{C}_{A}(t)}{1000}\right)
$$

\section{Humus}

$$
\begin{aligned}
& { }^{14} \dot{c}_{\mathrm{fH}}(t)=-(a+\lambda){ }^{14} c_{\mathrm{fH}}(t)+\sum_{\forall \text { litter } l} \xi_{l} k_{l}{ }^{14} c_{l}(t) \\
& \text { fast humus } \\
& { }^{14} \dot{c}_{\mathrm{sH}}(t)=-(a s+\lambda){ }^{14} c_{\mathrm{SH}}(t)+a \nu{ }^{14} c_{\mathrm{fH}}(t) \\
& \text { slow humus }
\end{aligned}
$$

${ }^{14} c_{j}$ and ${ }^{12} c_{j}$ denote the mass of ${ }^{14} \mathrm{C}$ (fractionation corrected) and ${ }^{12} \mathrm{C}$ of foliar $\left(j=\mathrm{flt}_{\mathrm{i}}, i=\{1, \ldots 6\}\right)$, fine $\operatorname{root}(j=\mathrm{frl})$, and woody litter $(j=\mathrm{wl})$, woody vegetation $(j=\mathrm{wt})$, fast $(j=\mathrm{fH})$, and slow humus $(j=\mathrm{sH})$. For the litter compartment $j,{ }^{12} \mathcal{F}_{\mathrm{V}, \mathrm{j}}$ denotes its steady state carbon input flux from vegetation, $k_{j}$ is its decay rate, and $\xi_{j}$ is the corresponding humification ratio (i.e., the fraction of decomposing litter that is not lost to the atmosphere as $\left.\mathrm{CO}_{2}\right)$. Here $\lambda$ is the radioactive decay rate of ${ }^{14} \mathrm{C}\left(8,267 \mathrm{yr}^{-1}\right)$ and ${ }^{14} \mathrm{R}_{\mathrm{st}}$ is the ${ }^{14} \mathrm{C}$ standard ratio $\left(\approx 10^{-12}\right)$.

Atmospheric ${ }^{14} \mathrm{C}$ concentrations $\left[\Delta^{14} \mathrm{C}_{\Lambda}(t)\right]$ are prescribed in $\Delta^{14} \mathrm{C}$ notation, thereby implicitly accounting for fractionation effects. Carbon 14 enrichment in living wood $\left({ }^{14} c_{\mathrm{wl}}\right)$ is explicitly modeled to account for the slower growth and turnover rates of these tissues. On the other hand, an instantaneous transter of the atmospheric ${ }^{14} \mathrm{C}$ signal is assumed for foliar $\left({ }^{14} c_{\mathrm{ftt}}\right)$ and fine root litter $\left({ }^{14} c_{\text {frl }}\right)$.

For comparison of simulated and measured ${ }^{14} \mathrm{C}$ enrichment data in leaf litter and mineral soil, simulated values were expressed as weighted averages and converted to $\Delta^{14} \mathrm{C}$ units consistently with the above equations:

$$
\begin{aligned}
\Delta^{14} \mathrm{C}_{\text {leaf litter, } \mathrm{n}}(t) & =\left[\frac{{ }^{14} R_{\text {leaf litter } \mathrm{n}}(t)}{{ }^{14} \mathrm{R}_{\mathrm{st}}}-1\right] 1000 \% \\
\Delta^{14} \mathrm{C}_{\text {humus }, \mathrm{n}}(t) & =\left[\frac{{ }^{14} R_{\text {humus }, \mathrm{n}}(t)}{{ }^{14} \mathrm{R}_{\mathrm{st}}}-1\right] 1000 \%
\end{aligned}
$$

where

$$
\begin{aligned}
{ }^{14} R_{\text {leaf litter, } \mathrm{n}}(t) & =\frac{\sum_{\forall \mathrm{flt}}{ }^{14} c_{i}(t)}{\sum_{\forall \mathrm{ftt}}{ }^{12} c_{i}(t)}, \\
{ }^{14} R_{\text {humus }, \mathrm{n}}(t) & =\frac{{ }^{14} c_{\mathrm{fH}}(t)+{ }^{14} c_{\mathrm{sH}}(t)}{{ }^{12} c_{\mathrm{fH}}+{ }^{12} c_{\mathrm{sH}}} .
\end{aligned}
$$

Net carbon fluxes between atmosphere and biota were neglected as they have a marginal impact on modeled $\Delta^{14} \mathrm{C}$ values. $\mathrm{C}$ stocks of litter and soil are assumed to be in steady state. This steady state assumption is unproblematic for the simulations of $\Delta^{14} \mathrm{C}$ values and ${ }^{14} \mathrm{C}$ inventories in litter and soils.

\section{Appendix B: Analytical Solution for Soil \\ Organic Carbon Response to a Step Change in Litter Input}

An analytical solution for the transient response of soil carbon stocks (see (4) and (5)) can be given if a step change in litter input is assumed. For litter input rates of the form $u(t)=u_{0}$ for $t \leq t_{0}$ and $u(t)=u_{0}(1+\delta)$ for $t>t_{0}$, one obtains

$c_{\mathrm{fH}}(t)= \begin{cases}\frac{u_{0}}{a} & t \leq t_{0} \\ \frac{u_{0}}{a}\left[1+\delta\left(1-e^{-a t}\right)\right] & \text { otherwise }\end{cases}$
$c_{\mathrm{sH}}(t)= \begin{cases}\frac{u_{0} \nu}{a s} & t \leq t_{0} \\ \frac{u_{0} \nu}{a s(1-s)}\left\{1+\delta\left(1-e^{-a s t}\right)\right. & \text { otherwise } \\ \left.-s\left[1+\delta\left(1-e^{-a t}\right)\right]\right\} & \end{cases}$

The relative increase of SOC stocks resulting from this increase in SOC input can be expressed as

$$
\begin{aligned}
\frac{c_{\mathrm{SOC}}(t)}{c_{\mathrm{SOC}}(0)}=\frac{\rho-s}{1-s} & {\left.\left[1+\delta\left(1-e^{-a t}\right)\right)\right] } \\
+ & \frac{1-\rho}{1-s}\left[1+\delta\left(1-e^{-a s t}\right)\right],
\end{aligned}
$$

where $\rho$ is the relative contribution of fast humus to total SOC stocks for $t \leq t_{0}$ :

$$
\rho=\frac{c_{\mathrm{fH}}}{c_{\mathrm{SOC}}}=\frac{c_{\mathrm{fH}}}{c_{\mathrm{fH}}+c_{\mathrm{SH}}}=\left(1+\frac{\nu}{s}\right)^{-1} .
$$

Acknowledgments. We thank K. Abbaspour for help with parameter identification and T. Harrison and D. Harkness for the stimulating discussions about their field and laboratory studies conducted at Meathop Wood. We are indebted to A. Burri who kindly provided us with archived soil samples for the Haumättli site and to N. Kuhn and J. Steck for providing information on the history of this site. Finally, we would like thank $\mathrm{H}$. Bugmann and two anonymous reviewers for their thoughtful suggestions and comments on a late version of this manuscript and R. Schulin and $\mathrm{H}$. Flühler for encouraging this work. F.J. appreciates the continuous support by 'T. Stocker and discussions with R. Meyer. 
This research was supported by grant 31-31142.91 of the Swiss National Science Foundation and ETH Zürich. F.J. acknowledges support by the Electric Power Research Institute (WO3441-06), by the Swiss National Science Foundation, and by the International Atomic Energy Agency (NO $8828 / \mathrm{CF})$.

\section{References}

Abbaspour, K. C., M. T. Van Genuchten, R. Schulin, and E. Schläppi, A sequential uncertainty domain inverse procedure for estimating subsurface flow and transport parameters, Water Resour. Res., 33(8), 1879-1892, 1997.

Aber, J. D., J. M. Melillo, and C. A. McClaugherty, Predicting long-term patterns of mass loss, nitrogen dynamics, and soil organic matter formation from initial fine litter chemistry in temperate forest ecosystems, Can. J. Bot., 68, 2201-2208, 1990.

Balesdent, J., G. H. Wagner, and A. Mariotti, Soil organic matter turnover in long-term field experiments as revealed by carbon-13 natural abundance, Soil Sci. Soc. Am. J., 52, 118-124, 1988.

Batjes, N. H., Total carbon and nitrogen in the soils of the world, Eur. J. Soil Sci., 47, 151-163, 1996.

Bazzaz, F. A., S. L. Miao, and P. M. Wayne, $\mathrm{CO}_{2}$-induced growth enhancements of co-occuring tree species decline at different rates, Oecologia, 96, 478-482, 1993.

Bugmann, H., and W. Cramer, Improving the behaviour of forest gap models along drought gradients, For. Ecol. Manage., 103, 247 263, 1998.

Bugmann, H. K. M., 1994, On the ecology of mountainous forests in a changing climate: A simulation study, Ph.D. thesis, publ. 10638, Swiss Fed. Inst. of Technol. Zürich, Switzerland.

Bugmann, H. K. M., A simplified forest model to study species composition along climate gradients, Ecology, 77(7), 2055-2074, 1996.

Bunce, R. G. H., Biomass and production of trees in a mixed deciduous woodland, J. Ecol., 56, 759-775, 1968.

Burke, I. C., C. M. Yonker, W. J. Parton, C. V. Cole, K. Flach, and D. S. Schimel, Texture, climate and cultivation effects on soil organic matter content in U.S. Grassland soils, Soil Sci. Soc. Am. J., 53, 800-805, 1989.

Burri, A., 1996, Retrospektive Erfassung von Veränderungen bodenchemischer Eigenschaften unter spezieller Berücksichtigung der Azidität, Ph.D. thesis, Univ. of Zürich, Zürich, Switzerland.

Buyanovsky, G. A., M. Aslam, and G. H. Wagner, Carbon turnover in soil physical fractions, Soil Sci. Soc. Am. $J ., 58,1167-1173,1994$.

Cambardella, C. A., and E. T. Elliott, Particulate soil organic-matter changes across a grassland cultivation sequencc, Soil Sci. Soc. Am. I., 56, 777-783, 1992.

Chertov, O. G., and A. S. Kornarov, SOMM - a model of sil organic matter and nitrogen dynamics in terrestrial ecosystems, in Evaluation of Soil Organic Matter Models Using Existing Long-Term Datasets, edited by D. S. Powlson, P. Smith, and J. U. Smith, pp. 231-236, SpringerVerlag, New York, 1996.

Comins, H. N., and R. E. McMurtrie, Longterm response of nutrient-limited forests to $\mathrm{CO}_{2}$ enrichment; equilibrium behavior of plant-soil models, Ecol. Appl., 3(4), 666-681, 1993.
Currie, W. S., and J. D. Aber, Modeling leaching as a decomposition process in humid, montane forests, Ecology, 78(6), 1844-1860, 1997.

Dai, A., and I. Y. Fung, Can climate variability contribute to the "missing" $\mathrm{CO}_{2}$ sink?, Global Biogeochem. Cycles, 7, 599-609, 1993.

De Angelis, D. L., R. H. Gardner, and H. H. Shugart, Productivity of forest ecosystems studied during the IBP: The woodland data set, in Dynamic Properties of Forest Ecosystems, edited by D. E. Reichle, pp. 567-672, Cambridge Univ. Press, New York, 1981.

Dixon, R. K., S. Brown, R. A. Houghton, A. M. Solomon, M. C. Trexler, and J. Wisniewski, Carbon pools and flux of global forest ecosystems, Science, 263, 185-190, 1994.

Dörr, H., and K. O. Münnich, Annual variations of the ${ }^{14} \mathrm{C}$ content of soil $\mathrm{CO}_{2}$, Radiocarbon, 28(2A), 338-345, 1986.

Enting, I. G., T. M. L. Wigley, and M. Heimann, Future emissions and concentrations of carbon dioxide: Key ocean/atmosphere/land analyses, Commonw. Sci. and Indis. Res. Org., CSIRO Technical Paper, 31, Melbourne, Australia, 1994.

Fischlin, A., H. Bugmann, and D. Gyalistras, Sensitivity of a forest ecosystem model to climate parametrization schemes, Environ. Poll., 87, 267-282, 1995.

Grigal, D. F., and L. F. Ohmann, Carbon storage in upland forests of the Lake States, Soil Sci. Soc. Am. J., 56, 935943, 1992.

Harkness, D. D., A. F. Harrison, and P. J. Bacon, The temporal distribution of 'bomb' ${ }^{14} \mathrm{C}$ in a forest soil, $R a$ diocarbon, 28(2A), 328-337, 1986.

Harrison, K. G., Using bulk soil radiocarbon measurements to estimate soil organic matter turnover times: Implications for atmospheric $\mathrm{CO}_{2}$ levels, Radiocarbon, 38(2), 181-190, 1996.

Harrison, A. F., and D. D. Harkness, Potential for estimating carbon fluxes in forest soils using ${ }^{14} \mathrm{C}$ techniques, $N$. Z. J. For. Sci., 23(3), 367-379, 1993.

Harrison, A. F., D. D. Harkness, and P. J. Bacon, The use of bomb- ${ }^{14} \mathrm{C}$ for studying organic matter and $\mathrm{N}$ and $\mathrm{P}$ dynamics in a woodland soil, in Nutrient Cycling in Terrestrial Ecosystems - Field Methods, Application and Interpretation, edited by A. F. Harrison, P. Ineson, and O. W. Heal, pp. 246-258, Elsevier Sci., New York, 1990.

Harrison, K. G., W. Broecker, and G. Bonani, A strategy for estimating the impact of $\mathrm{CO}_{2}$ fertilization on soil carbon storage, Global Biogeochem. Cycles, 7(1), 69-80, 1993a.

Harrison, K. G., W. S. Broecker, and G. Bonani, The effect of changing land use on soil radiocarbon, Science, 262, 725-726, 1993b.

Harrison, K. G., W. M. Post, and D. D. Richter, Soil carbon turnover in a recovering temperate forest, Global Biogeochem. Cycles, 9(4), 449-454, 1995.

Hassink, J., Decomposition rate constants of size and density fractions of soil organic matter, Soil Sci. Soc. Am. $J .$, 59, 1631-1635, 1995.

Hesshaimer, V., M. Heimann, and I. Levin, Radiocarbon evidence for a smalier carbon dioxide sink than previously believed, Nature, 370, 210-203, 1994.

Hohmann, P. S., P. Sollins, H. N. Chappell, and A. G. Stangenberger, Soil organic carbon in a mountainous forested region: Relation to site characteristics, Soil Sci. Soc. Am. J., 59, 1468-1475, 1995.

Hsieh, Y. P., Pool size and mean age of stable soil organic 
carbon in cropland, Soil Sci. Soc. Am. J., 56, 460-464, 1992.

Hsieh, Y. P., Radiocarbon signatures of turnover rates in active soil organic carbon pools, Soil Sci. Soc. Am. J., 57, 1020-1022, 1993.

Huntington, T. G., D. F. Ryan, and S. P. Hamburg, Estimating soil nitrogen and carbon pools in a northern hardwood forest ecosystem, Soil Sci. Soc. Am. J., 52, 1162-1167, 1988.

Jackson, R. B., H. A. Mooney, and E. Schulze, A global budget for fine root biomass, surface area, and nutrient contents, Proc. Nat. Acad. Sci. U.S.A., 94, 7362-7366, 1997.

Jenkinson, D. S., The turnover of organic carbon and nitrogen in soil, Philos. Trans. R. Soc. London, Ser. B, 329, 361-368, 1990.

Jenkinson, D. S., and J. H. Rayner, The turnover of soil organic matter in some of the Rothamsted classical experiments, Soil Sci., 123, 298-305, 1977.

Joos, F., Imbalance in the budget, Nature, 370, 181-182, 1994.

Joos, F., and M. Bruno, Long-term variability of the terrestrial and oceanic carbon sinks and the budgets of the carbon isotopes ${ }^{13} \mathrm{C}$ and ${ }^{14} \mathrm{C}$, Glibal Biogeochem. Cycles, 12, 277-295, 1998.

Joos, F., M. Bruno, R. Fink, T. F. Stocker, U. Siegenthaler, C. Le Quéré, and J. L. Sarmiento, An efficient and accurate representation of complex oceanic and biospheric models of anthropogenic carbon uptake, Tellus, Ser. B, 48, 397-417, 1996.

Joos, F., R. Meyer, M. Heimann, and G. Esser, Validating high-resolution terrestrial biosphere models (TBM) using radiocarbon observations, in Paper presented at fifth International $\mathrm{CO}_{2}$ Conference, CSIRO Atmos. Res., Queensland 8-12 Sept. 1997, pp. 264-265, 1997.

King, A. W., W. M. Post, and S. D. Wullschleger, The potential response of terrestrial carbon storage to changes in climate and atmospheric $\mathrm{CO}_{2}$, Clim. Change, 35, 199227, 1997.

Kirschbaum, M. U. F., and A. Fischlin, Climate change impacts on forests, in Climate Change 1995 - Impacts, Adaptions and Mitigation of Climate Change: ScientificTechnical Analyses, edited by R. T. Watson, M. C. Zinyowera, and R. H. Moss, pp. 97-129, Cambridge Univ. Press, New York, 1996.

Körner, C., and J. A. Arnone III, Responses to elevated carbon dioxide in artificial tropical ecosystems, Science, 257, 1672-1675, 1992.

Kuhn, N., Veränderungen von Waldstandorten. Schlussberichte Sanasilva 1984-1987, Eidg. Forsch. für Wald, Schnee und Landschaft, Rep., 319, Birmensdorf, Switzerland, 1990.

Liski, J., and C. J. Westman, Density of organic carbon in a soil at coniferous forest sites in Southern Finland, Biogeochemistry, 29(3), 183-197, 1995.

Lüscher, P., 1991, Humusbildung und Humusumwandlung in Waldbeständen, Ph.D. thesis, publ. 9572, Swiss Fed. Inst. of Technol. Zürich, Switzerland.

Matthews, E., Global litter production, pools, and turnover times: Estimates from measurement data and regression models, J. Geophys. Res., 102(D15), 18771-18800, 1997.

Mattson, K. G., W. T. Swank, and J. B. Waide, Decomposition of woody debris in a regenerating, clear-cut forest in the Southern Appalachians, Can. J. For. Res., 17, 712$721,1987$.
McGuire, A. D., J. M. Melillo, D. W. Kicklighter, and L. A. Joyce, Equilibrium responses of soil carbon to climate change: Empirical and process-based estimates, J. Biogeography, 22, 785-796, 1995.

Meentemeyer, V., Macroclimate and lignin control of litter decomposition rates, Ecology, 59, 465-472, 1978.

Meentemeyer, V., E. O. Box, and R. Thompson, World patterns and amounts of terrestrial plant litter production, Bioscience, 32(2), 125-128, 1982.

Melillo, J. M., D. W. Kicklighter, A. D. McGuire, W. T. Peterjohn, and K. M. Newkirk, Global change and its effects on soil organic carbon stocks, in The Role of Nonliving Organic Matter in the Earth's Carbon Cycle, edited by R. G. Zepp and C. Sonntag, pp. 175-189, John Wiley \& Sons, Ltd., New York, 1995.

Melillo, J. M., I. C. Prentice, G. D. Farquhar, E. Schulze, and O. E. Sala, Terrestrial biotic responses to environmental change and feedbacks to climate, in Climate change 1995: The Science of Climate Change, edited by J. T. Houghton, et al., pp. 449-481, Cambridge Univ. Press, New York, 1996.

Motavalli, P., C. A. Palm, W. J. Parton, E. T. Elliott, and S. D. Frey, Comparison of laboratory and modeling simulation methods for estimating soil carbon pools in tropical forest soils, Soil Biol. Biochem., 26 (8), 935-944, 1994.

Nadelhoffer, K. J., and J. W. Raich, Fine root production estimates and belowground carbon allocation in forest ecosystems, Ecology, 73, 1139-1147, 1992.

Norby, R. J., C. A. Gunderson, S. D. Wullschleger, E. G. O'Neill, and M. K. McCracken, Productivity and compensatory responses of yellow-poplar trees in elevated $\mathrm{CO}_{2}$, Nature, 357, 322 324, 1992.

Parton, W. J., D. S. Schimel, C. V. Cole, and D. S. Ojima, Analysis of factors controlling soil organic matter levels in Great Plain Grasslands, Soil Sci. Soc. Am. J., 51, 11731179, 1987.

Parton, W. J., et al., Observations and modelling of biomass and soil organic matter dynamics for the grassland biome worldwide, Global Biogeochem. Cycles, 7(4), 785-809, 1993.

Parton, W. J., D. S. Schimel, D. S. Ojima, and C. V. Cole, A general model for soil organic matter dynamics: Sensitivity to litter chemistry, texture and management, in Quantitative Modeling of Soil Forming Processes 39, edited by R. B. Bryant, pp. 147-167, Soil Science Society of America, Madison, Wisc., 1994.

Pastor, J., and W. M. Post, Development of a linked productivity-soil process model, Oak Ridge Nat. Lab., Rep. ORNL, 2455, Oak Ridge, Tenn., 1985.

Perruchoud, D. O., 1996, Modeling the dynamics of nonliving organic carbon in a changing climate: A case study for temperate forests, Ph.D. thesis, publ. 11900, Swiss Fed. Inst. of Technol. Zürich, Switzerland.

Perruchoud, D. O., and A. Fischlin, The response of the carbon cycle in undisturbed forest ecosystems to climate change: A review of plant-soil models, J. Biogeography, 22, 759-774, 1995.

Post, W. M., A. W. King, and S. D. Wullschleger, Historical variations in terrestrial biospheric carbon storage, Global Biogeochem. Cycles, 11(1), 99-109, 1997.

Potter, C. S., J. T. Randerson, C. B. Field, P. A. Matson, P. M. Vitousek, H. A. Mooney, and S. A. Klooster, Terrestrial ecosystem production: A process model based on global satellite and surface data, Global Biogeochem. Cycles, 7, 811-841, 1993. 
Rafter, T. A., and J. D. Stout, Radiocarbon measurements as an index of the rate of turnover of organic matter in forests and grassland ecosystems in New Zealand, in $R a$ diocarbon Variations and Absolute Chronology, Proceedings of the Twelfth Nobel Symposium. Uppsala, Sweden, edited by I. U. Olsson, pp. 401-417, Wiley, Intersci., New York, 1970.

Raich, J. W., and C. S. Potter, Global patterns of carbon dioxide emissions from soils, Global Biogeochem. Cycles, 9, 23-36, 1995.

Raich, J. W., and W. H. Schlesinger, The global carbon dioxide flux in soil respiration and its relationship to vegetation and climate, Tellus, Ser. B, 44, 81-99, 1992.

Rastetter, E. B., M. Ryan, G. R. Shaver, J. M. Melillo, K. J. Nadelhoffer, J. E. Hobbie, and J. D. Aber, A general biogeochemical model describing the responses of the $\mathrm{C}$ and $\mathrm{N}$ cycles in terrestrial ecosystems to changes in $\mathrm{CO}_{2}$, climate, and N deposition, Tree Physiol., 9, 101-126, 1991.

Rouhier, H., G. Billes, A. El Kohen, M. Mousseau, and P. Bottner, Effect of elevated $\mathrm{CO}_{2}$ on carbon and nitrogen distribution within a tree (castanea sativa Mill.) soil system, Plant Soil, 162, 281-292, 1994.

Rutberg, R. L., D. S. Schimel, I. Hajdas, and W. S. Broecker, The effect of tillage on soil organic matter using 14C: A case study, Radiocarbon, 38(2), 209-217, 1996.

Scharpenseel, H. W., Major carbon reservoirs of the pedosphere; source-sink relations; potential of the ${ }^{14} \mathrm{C}$ and $\delta{ }^{13} \mathrm{C}$ as supporting methodologies, Water, Air Soil Poll., 70, 431-442, 1993.

Schimel, D. S., B. H. Braswell, E. A. Holland, R. McKweon, D. S. Ojima, T. H. Painter, W. J. Parton, and A. R. Townsend, Climatic, edaphic, and biotic controls over storage and turnover of carbon in soils, Global Biogeochem. Cycles, 8, 279-293, 1994.

Schimel, D., 1. G. Enting, M. Heimann, T. M. L. Wigley, D. Raynaud, D. Alves, and U. Siegenthaler, $\mathrm{CO}_{2}$ and the carbon cycle, in Climate Change 1994 - Radiative Forcing of Climate Change and an Evaluation of the IPCC IS92 Emission Scenario, edited by J. T. Houghton, et al., pp. 39-71, Cambridge Univ. Press, New York, 1995.

Schimel, D., et al., Radiative forcing of climate change, in Climate change 1995: The Science of Climate Change, edited by J. T. Houghton, et al., pp. 69-131, Cambridge Univ. Press, New York, 1996.

Schimel, D., D. Alves, I. G. Enting, M. Heimann, F. Joos, D. Raynaud, and T. M. L. Wigley, $\mathrm{CO}_{2}$ and the carbon cycle, in IPCC Second Scientific Assessment of Climate Change, edited by J. T. Houghton, et al., pp. 76-86, Cambridge Univ. Press, New York, 1996.

Schlesinger, W. H., Carbon balance in terrestrial detritus, Annual Review of Ecological Systems, 8, 51-81, 1977.

Schlesinger, W. H., Evidence from chronosequence studies for a low carbon-storage potential of soils, Nature, 348, 232-234, 1990.

Sykes, J. M., and R. G. H. Bunce, Fluctuations in litter-fall in a mixed deciduous woodland over a three-year period 1966-1968, Oikos, 21, 326-329, 1970.

Tate, K. R., A. Parshotam, and D. J. Ross, Soil carbon storage and turnover in temperate forests and grasslands - A New Zealand perspective, J. Biogeography, 22, 695700,1995
Theng, B. K., K. R. Tate, and P. Becker-Heidmann, Towards establishing the age, location, and identity of the inert soil organic matter of a spodosol, Z. Pflanzenernährung Bodenkunde, 155, 181-184, 1992.

Townsend, A. R., P. M. Vitousek, and S. E. Trumbore, Soil organic matter dynamics along gradients in temperature and land use on the island of Hawaii, Ecology, 76(3), 721-733, 1995.

Trumbore, S. E., Comparison of carbon dynamics in tropical and temperate soils using radiocarbon measurements, Global Biogeochem. Cycles, 7, 275-290, 1993.

Trumbore, S. E., O. A. Chadwick, and R. Amundson, Rapid exchange between soil carbon and atmospheric carbon dioxide driven by temperature change, Science, 272, 393396, 1996.

Trumbore, S. E., E. A. Davidson, P. Barbosa de Camargo, D. C. Nepstad, and L. A. Martinelli, Belowground cycling of carbon in forests and pastures of eastern Amazonia, Global Biogeochem. Cycles, 9(4), 515-528, 1995.

Trumbore, S. E., and E. R. M. Druffel, Carbon isotopes for characterizing sources and turnover of nonliving organic matter, in The Role of Nonliving Organic Matter in the Earth's Carbon Cycle, edited by R. G. Zepp and C. Sonntag, pp. 7-22, John Wiley \& Sons, New York, 1995.

Trumbore, S. E., J. S. Vogel, and J. R. Southon, AMS C14 measurements of fractionated soil organic matter: An approach to deciphering the soil carbon cycle, Radiocarbon, 31, 644-654, 1989.

Verberne, E. L. J., J. Hassink, P. De Willigen, J. J. R. Groot, and J. A. Van Veen, Modelling organic matter dynamics in different soils, Neth. J. Agric. Sci., 38, 221-238, 1990.

Waring, R. H., and W. H. Schlesinger, Forest Ecosystems Concepts and Management, Academic, San Diego, Calif., 1985.

Wullschleger, S. D., A. W. King, and W. M. Post, On the potential for a $\mathrm{CO}_{2}$ fertilization effect in forest trees: An assessment of 58 controlled-exposure studies and estimates of the biotic growth factor, in Biotic Feedbacks in the Global Climate System, edited by G. M. Woodwell and F. T. Mackenzie, pp. 85-107, Oxford Univ. Press, New York, 1995.

G. Bonani and I. Hajdas, Institute of Particle Physics, Swiss Federal Institute of Technology Zürich, 8093 Hönggerberg, Switzerland. (e-mail: bonani@particle.phys.ethz.ch; hajdas@particle.phys.ethz.ch)

A. Fischlin, Systems Ecology, Institute of Terrestrial Ecology, Swiss Federal Institute of Technology Zürich, 8952 Schlieren, Switzerland. (e-mail: fischlin@ito.umnw.ethz.ch)

F. Joos, Climate and Environmental Physics, Physics Institute, University of Bern, 3012 Bern, Switzerland. (e-mail: joos@climate.unibe.ch)

D. Perruchoud, National Forest Inventory, Swiss Federal Institute for Forest, Snow and Landscape Research (WSL), 8903 Birmensdorf, Switzerland. (e-mail: perruchoud@wsl.ch)

(Received June 3, 1998; revised December 10, 1998; accepted January 22, 1999.) 